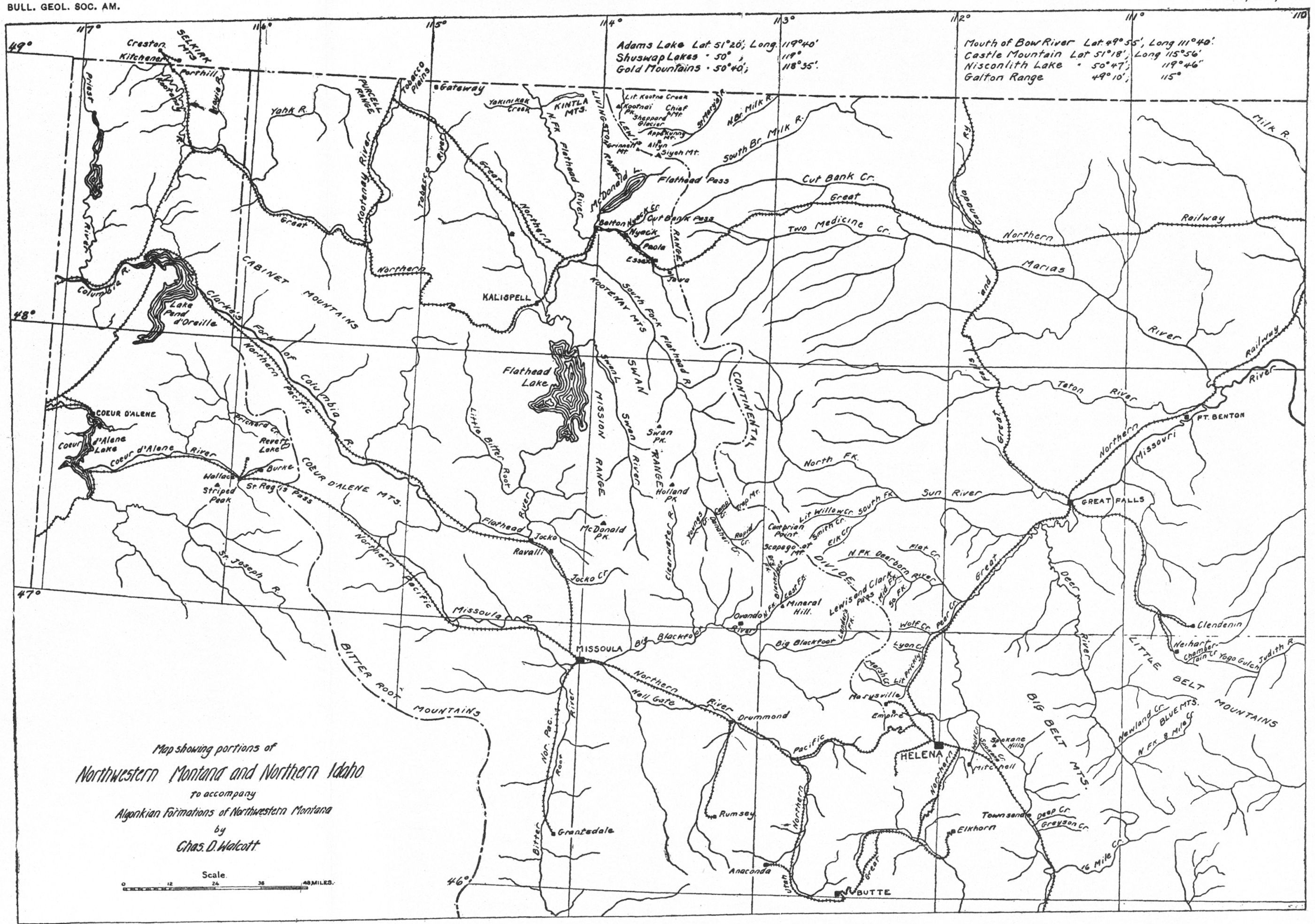

MAP OF PORTIONS OF NORTHWESTERN MONTANA AND NORTHERN IDAHO 


\title{
ALGONKIAN FORMATIONS OF NORTHWESTERN MONTANA
}

\author{
BY CHARLES D. WALCOTT
}

(Presented by title before the Society December 29, 1905)

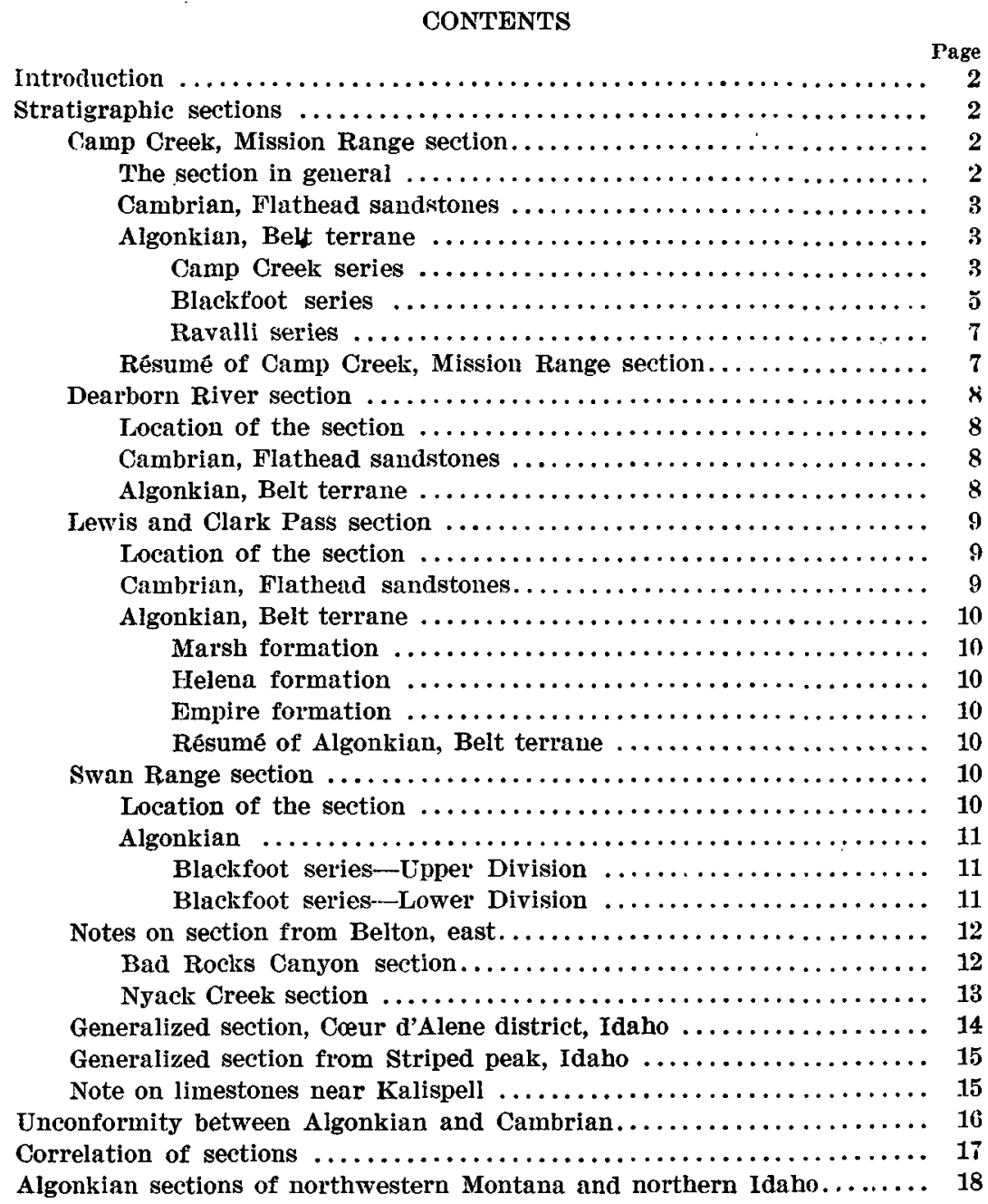


Correlation of Montanian with Canadian sections $\ldots \ldots \ldots \ldots \ldots \ldots \ldots \ldots .21$

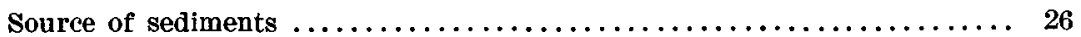

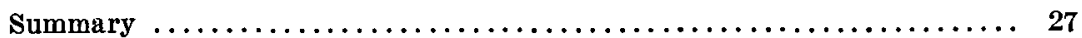

\section{INTRODUCTION}

In 1898 I made a reconnaissance of the pre-Cambrian formations of the Belt mountains of Montana and published the results.* The section extended from the unconformable Cambrian above to Archean complex at the base. In $1900 \mathrm{I}$ crossed the Belt mountains and endeavored to trace the connection, north of Helena, of the Belt terrane and the preCambrian rocks of the Rocky Mountain "front" at Lewis and Clark pass and north on the south fork of the Dearborn river. It was evident that a great series of strata extended westward beneath the Cambrian that was in general similar to the Belt terrane, but quite different in detail. In 1901, at my request, Mr Bailey Willis studied the Front ranges of the Rocky mountains in northern Montana and found a great series of strata referred to the Algonkian. $\nmid$ In the survey of the Cour d'Alene mining district of Idaho Mr F. L. Ransome, assisted by Mr F. C. Calkins, found most of the region underlain by stratified, siliceous rocks, referred to the Algonkian.f During the field season of $1905 \mathrm{Mr}$ Calkins continued the study of the Algonkian rocks of Idaho, and extended his examinations into western Montana, nearly to Ravalli, on the Northern Pacific railroad. I also had the opportunity of studying the pre-Cambrian rocks of northwestern Montana in 1905, and of measuring the section from northwest of Scapegoat mountain on the Continental divide, westward, crossing the Swan and Mission ranges, to the canyon of Jocko creek above Ravalli.

In this paper I wish to compare the various sections thus far studied and to correlate them as far as practicable. The Camp Creek, Mission Range section will be taken as the type section, owing to its being capped by Cambrian strata and being of greater vertical range than any other known section. It embraces portions of the northern section of $\mathrm{Mr}$ Willis and the western section in the Coeur d'Alene district.

\section{Stratigraphic Sections}

\section{CAMP CREEK, MISSION RANGE SECTION}

The section in general.-The upper portion of Scapegoat mountain, in the southeastern portion of the Lewis and Clark forest reserve, is formed

* Bull. Geol. Soc. Am., vol. 10, pp. 201-215, 235-239.

$\dagger$ Bull. Geol. Soc. Am., vol. 13, pp. 314-324.

† Manuscript of Geologlc Folio, U. S. Geological Survey. 

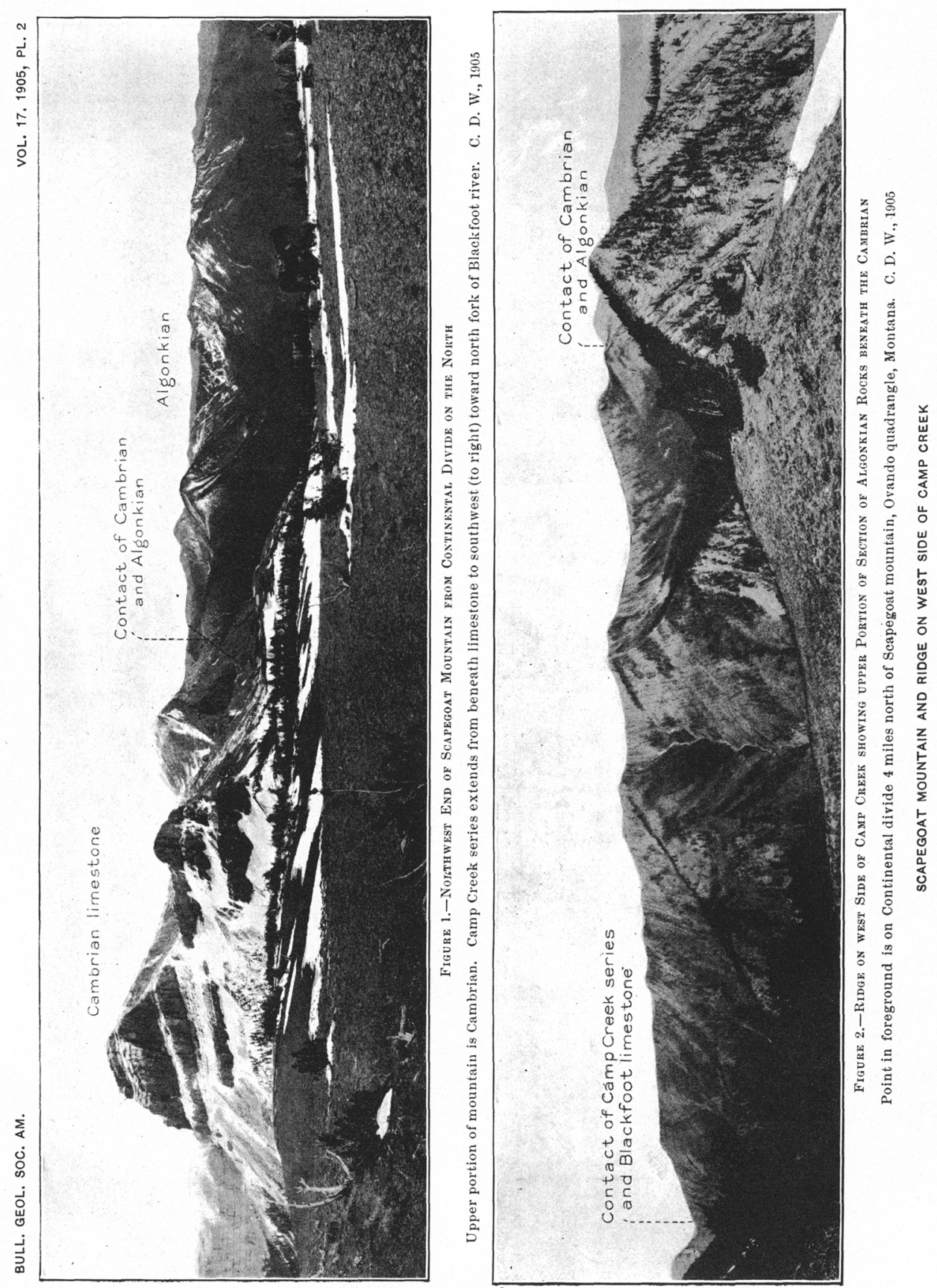


$$
\text { . }
$$


of a great mass of Cambrian limestone, extending 6 miles on a northwestsoutheast axis and varying in width from one to two miles (see plate 2, figure 1). The southeast point is Scapegoat $(9,185$ feet elevation) and the northwest elevation (9,000 feet) I shall call Cambria. The limestones are superjacent to siliceous Algonkian strata forming the main ridge of the Continental divide and the spurs descending from it on the north, west, south, and southeast. On the east and northeast the Cambrian limestones slope toward the Dearborn River drainage.

After a reconnaissance of the area I decided to measure the Algonkian section at localities where each of its units, or formations, were well exposed and in contact above and below with other known formations.

For the first, or upper, series of strata the sharp ridges on the southeast and northwest sides of Camp creek were selected (see plate 2, figure 2). Camp creek heads close to the Continental divide, northwesi of Trap mountain, and 12 miles northwest of Cambrian point. It flows south-southwest to where it enters Danaher creek, 4 miles above the head of the south fork of the Flathead river.*

Cambrian, Flathead sandstones.-The massive, coarse grained sandstones of the Flathead series overlie the Algonkian strata of the Camp Creek, Mission Range section at the summit of the Continental divide.

The fine conglomerate at the base of the Flathead sandstone of the Middle Cambrian rests in apparent conformity on the Algonkian strata, the layers of both formations dipping north at an angle of 70 degrees.

Algonkian, Belt terrane.-The Algonkian strata of the Camp Creek, Mission Range section, comprise three great series, the Camp Creek, the Blackfoot, and the Ravalli, as follows:

\section{Camp Creek series}

1a. Compact, hard, gray sandstones, almost quartzitic in

Feet Feet many layers; layers vary in thickness from one-fourth inch to 10 inches; often marked by mud cracks and ripples; toward the top the dip is about 70 degrees north; 500 feet in thickness below, the dip increases to 80 degrees, and decreases to 75 degrees near the base....

From this point the section was measured on the east side of Camp creek.

2a. Reddish brown, arenaceous shales and thin bedded limestones, alternating irregularly with greenish gray bands of shales and sandstones. Some of the thicker layers, 2 to 6 inches, are almost quartzitic......... $1,560 \quad 1,560$

* See topographic map of Ovando quadrangle, Montana.

$\dagger$ All thicknesses, unless otherwise stated, were obtained by measuring the strata with rod and clinometer, a method that gives reliable results. (See Proc. U. S. Nat. Museum, 1888, vol. $x i$, p. 447.) 
3a. Greenish, sandy shales, with thin layers of greenish gray, compact sandstone at irregular intervals............

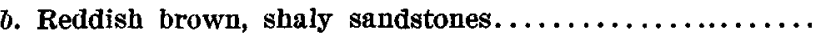

$c$. Reddish brown, thin bedded sandstones, becoming more massive, compact, and almost quartzitic 50 to 75 feet down. About 50 feet from the base the layers are more or less cross-bedded, coarser grained, reddish gray in color, and from 2 to 14 inches in thickness....

$d$. Reddish brown sandstones that, 285 feet from the top, gradually pass into alternating thin bedded, reddish colored, sandy shales and sandstones. Toward the base there is 60 feet of reddish and green, sandy

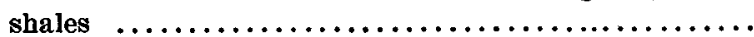

e. Reddish brown, thin bedded and shaly sandstones. Ripple markings and mud cracks occur abundantly in

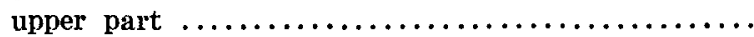

f. Grayish red sandstone in layers 8 inches to 2 feet thick, alternating with shaly sandstone bands and partings..

y. Reddish brown sandstones and shaly beds............

4. Alternating thin bedded, gray, hard sandstones and sandy shales, alternating with an occasional quartzitic sandstone; layers 8 to 12 inches thick. At 360 feet down light gray, sandy shales, slightly calcareous in places, have a thickness of about 30 feet. Below, the sandstone layers are thicker, with less shaly beds, and almost quartzitic in the thicker layers. At 175 feet from the top a reddish brown belt 15 feet thick occurs; otherwise this great gray sandstone band and a similar band below $(6 c)$ are conspicuons features in the ridges, as the gray color is in strong contrast with the rich, reddish brown bands. Ripple marks and mud cracks are of frequent occurrence...........

5. Compact, impure, gray limestone, siliceous, arenaceous, thin bedded, and shaly, weathering buff to yellow on

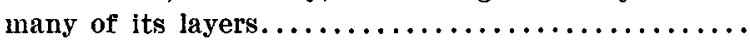

6a. Gray sandstones in layers 2 to 8 inches thick, with alternating bands and parting of shaly sandstones.........

b. Reddish brown, thin bedded, and shaly sandstones......

Sixteen feet from the top a layer about 15 inches thick is nearly made up of irregularly semispherical masses of Cryptozoan. The latter are calcareous in an impure saudstone matrix.

c. Gray, shaly, and thin bedded, compact sandstone.......

A bed of Cryptozoan occurs 325 feet below the summit, in a rough, gray sundstone layer about 4 feet thick. 
7a. Reddish brown sundstones, thin bedded and often shaly..

b. Gray, thin bedded, and almost shaly sandstones, with mud cracks and ripple marks.................... 158

c. Reddish brown, thin bedded, and often shaly sandstones..

d. Gray, thin bedded, and shaly sandstones, with mud cracks, wave and ripple markings......................

$e$. Chocolate red, thin bedded sandstones, alternating with impure, gray, arenaceous limestone layers......... 395

Cryptozoan is abundant in small forms in a layer 6 inches thick, 25 feet from the top.

\section{Résumé}

\begin{tabular}{|c|c|c|}
\hline \multirow{3}{*}{ 1. Gray sandstones $\ldots \ldots \ldots \ldots \ldots \ldots \ldots \ldots \ldots \ldots \ldots \ldots$} & \multirow{2}{*}{ Feet } & \multirow{2}{*}{ Feet } \\
\hline & & \\
\hline & 1,762 & 1,762 \\
\hline 2a. Reddish sandstones $\ldots \ldots \ldots \ldots \ldots \ldots \ldots \ldots \ldots \ldots \ldots \ldots$ & 1,560 & 1,560 \\
\hline 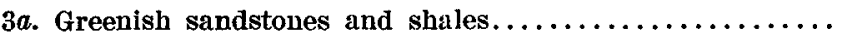 & 612 & \\
\hline$c-d$. Reddish brown sandstones. $\ldots \ldots \ldots \ldots \ldots \ldots \ldots \ldots$ & 2,332 & \\
\hline 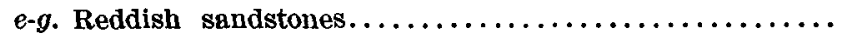 & 1,496 & \\
\hline 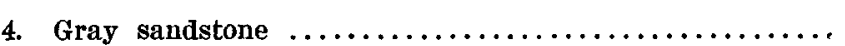 & 700 & 700 \\
\hline Siliceous limestone $\ldots \ldots \ldots \ldots \ldots \ldots \ldots \ldots \ldots \ldots \ldots$ & 198 & 198 \\
\hline $6 a$. Gray sandstone $\ldots \ldots \ldots \ldots \ldots \ldots \ldots \ldots \ldots \ldots \ldots$ & 482 & \\
\hline b. Reddish sandstone $\ldots \ldots \ldots \ldots \ldots \ldots \ldots \ldots \ldots \ldots \ldots$ & 68 & \\
\hline 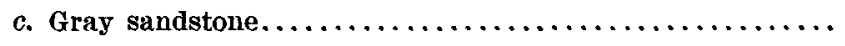 & 425 & \\
\hline 7a. Reddish sandstone .. & 753 & \\
\hline 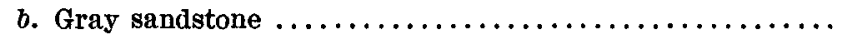 & 158 & \\
\hline$c$. Reddish sandstone $\ldots \ldots \ldots \ldots \ldots \ldots \ldots \ldots \ldots \ldots \ldots \ldots$ & 623 & \\
\hline 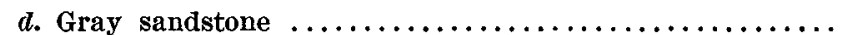 & 85 & \\
\hline e. Reddish sandstone $\ldots \ldots \ldots \ldots \ldots \ldots \ldots \ldots \ldots \ldots$ & 395 & \\
\hline & & 2,014 \\
\hline Total of Camp Creek series... & & 11,700 \\
\hline
\end{tabular}

\section{Blackfoot series}

Type locality of Blackfoot series: Canyon of North fork of Blackfoot river, where the entire section is exposed.

The red beds of the Camp Creek series rest conformably on the limestones of the Blackfoot series, about a mile above the mouth of Camp creek. The contact between the two formations can be traced for many miles to the north, south, and southeast. At Camp creek the Blackfoot limestones are broken by a fault in the canyon valley of Danaher creek, but to the south, 10 miles west of south of Scapegoat mountain, the entire section of the limestone is shown conformably beneath the Camp Creek terrane in fine exposures in the canyon of the north fork of Blackfoot 
river, below Dry fork. The section was measured on the high ridge east of the river, and passes over Mineral hill.

Above the Blackfoot limestones the red and gray arenaceous beds of the Camp Creek series extend northward and pass beneath the Cambrian strata of Scapegoat mountain.

1. Passage bends; sandy layers, pinkish to dull red, with coarser grains of sand than below, followed by grayish, buff weathering, slightly calcareous, fine grained sandstones. The upper half has more buff and yellowish beds and the lower half more of the reddish beds......

2. Shaly limestones, alternating with thin layers of gray limestone. Near the top a few oolitic layers occur, and throughout are occasional layers with Cryptozoan. About 730 feet down the shaly beds give way to bedded, gray limestone, alternating with impure, dark gray, buff weathering limestone. About 160 feet from the base the shaly limestone again predominates, with frequent layers of oolitic and siliceous limestone...... Cryptozoan is abundant in the lower 100 feet.

3. Calcareous shales with bands of green arenaceous shale...

4. Thin bedded and shaly, gray limestone, with occasional layers of gray limestone 2 to 10 inches thick. In the lower 70 feet, oolitic layers and semi-cherty layers occur. The siliceous portions of the latter weather buff and the irregular nodules and stringers of gray limestone a bluish gray $\ldots \ldots \ldots \ldots \ldots \ldots \ldots \ldots \ldots \ldots$

Cryptozoan occurs abundantly in the upper 60 feet on the high point north-northeast of Mineral hill. Fine specimens of Cryptozoan two feet and more in diameter occur in beds 3 feet thick at horizons 360 and 373 feet below the top.

5. Thin bedded, more or less shaly, compact, gray limestone, weathering buff and gray......................

6. Gray limestone in layers 8 to 20 inches thick, with irregular nodules and stringers of cherty matter, weathering buff. This extends down about 330 feet, where there is a gradual change into banded culcareous and siliceous beds, with layers of gray limestone. These give way 1,040 feet down to gray, compact, siliceous, buff weathering limestone in shaly bands and thin layers. Siliceous matter becomes more prominent, until the only evidence of calcareous matter is the buff weathering beds. $A$ bed 28 feet thick of purplish colored, siliceous rock, in hard, compact, smooth layers, occurs 285 feet above the base.......................

Cryptozoan of large size, 15 inches and more in Feet Feet diameter, occur 165 feet from the top. 


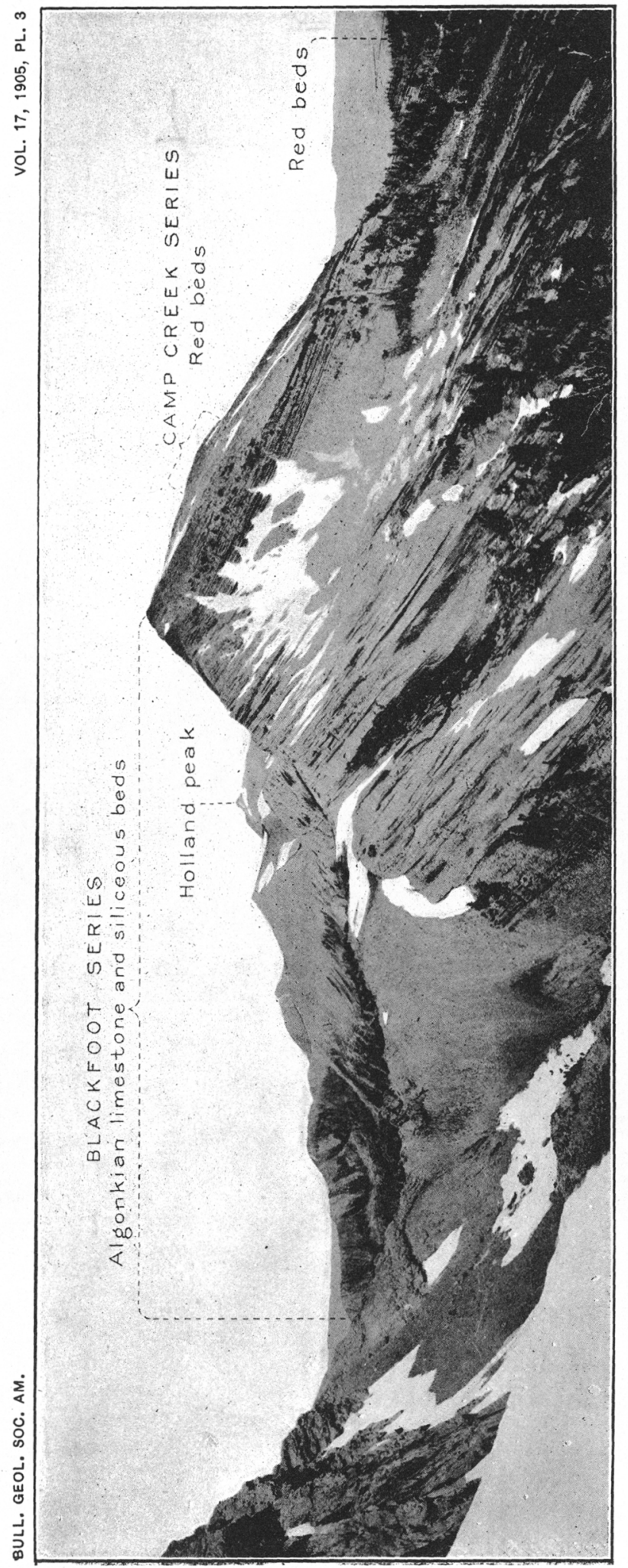

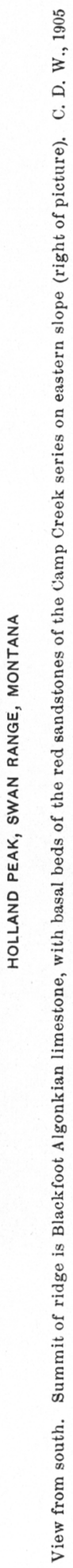


BULL. GEOL. SOC. AM.

VOL. 17, 1905, PL. 4

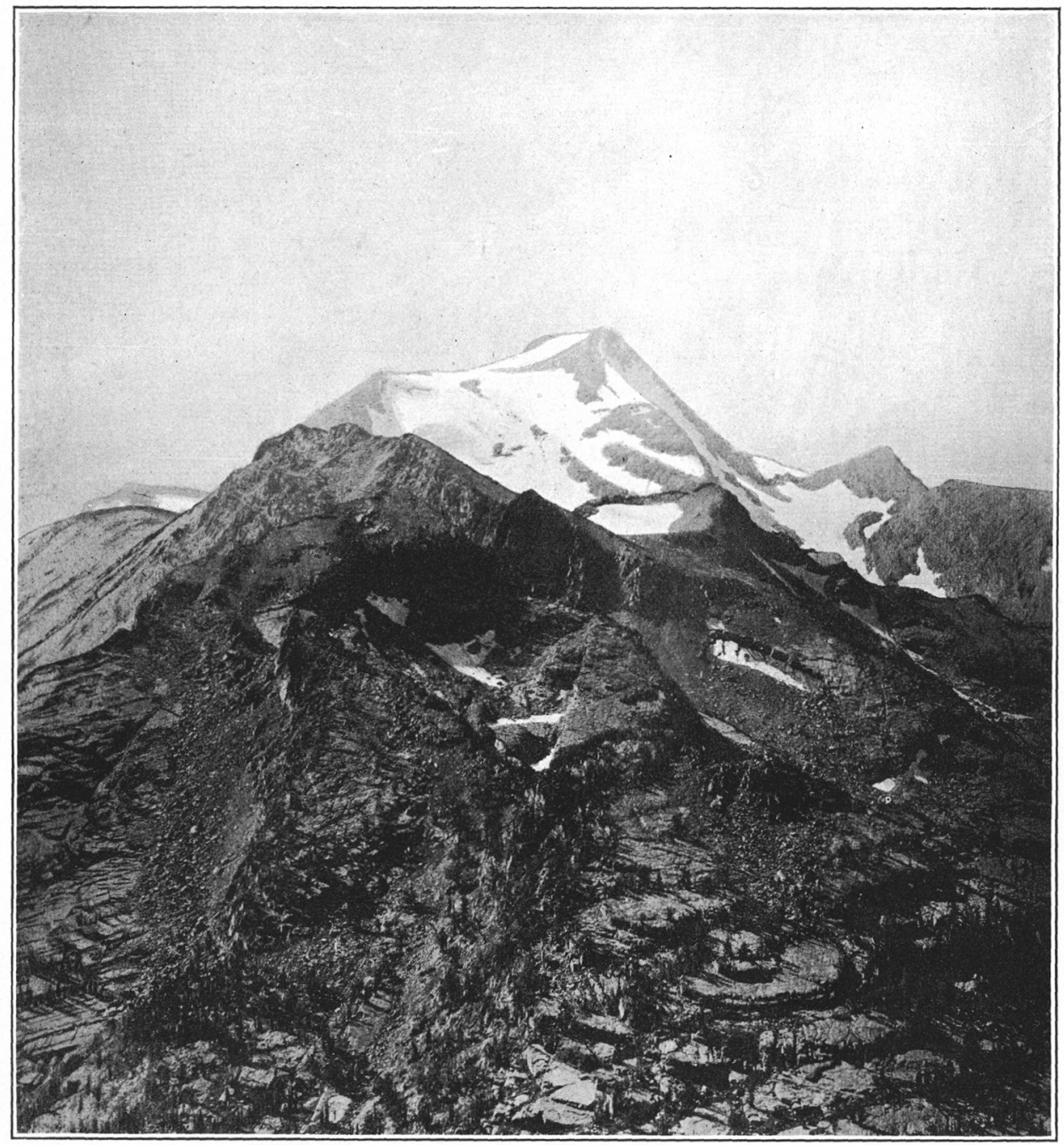

SOUTHEASTERN SLOPE OF MOUNT MCDONALD, MISSION RANGE, MONTANA

The strata forming Mount McDonald are the calcareous and siliceous beds of the Blackfoot series. C. D. W., 1900 


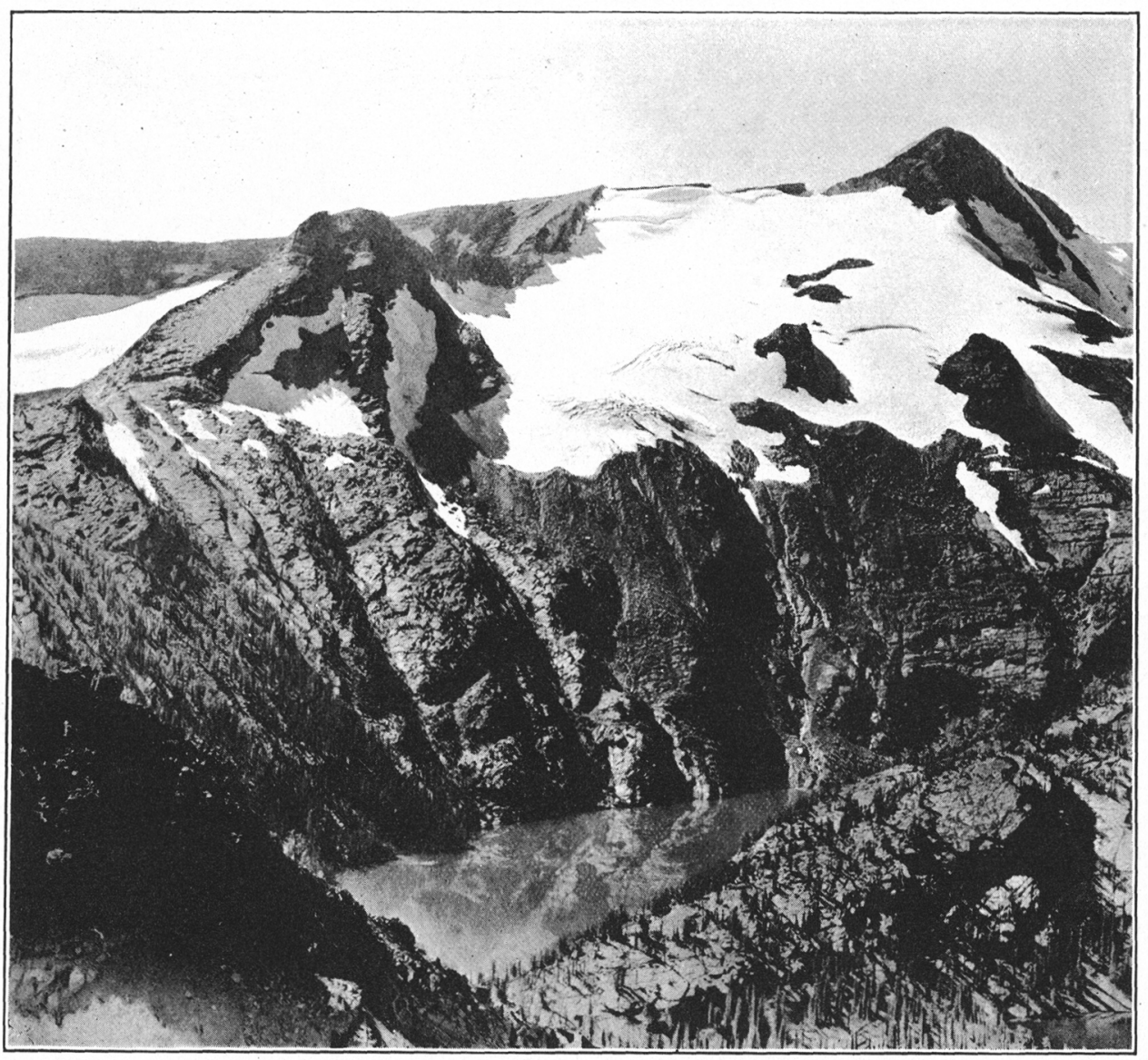

CREST OF MISSION RANGE, MONTANA

This view, taken a short distance south of Mount MeDonald, shows the effect of glacial erosion on the slightly altered calcareous and siliceous beds of the Blackfoot series. C. D. W., 1900 
.

, 


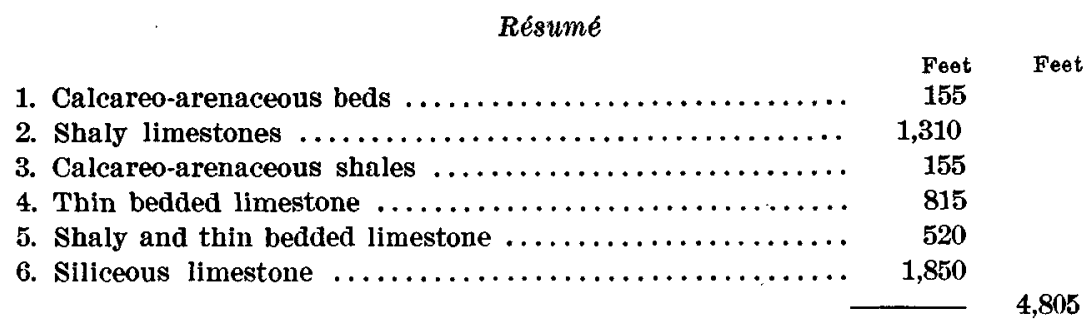

In this section, below the Blackfoot series, the purple and green siliceous beds of the Ravalli series have a thickness of 2,150 feet to a fault 2.5 miles south of Mineral hill.

\section{Ravalli series}

The Blackfoot Limestone series, with the siliceous red beds above and purple beds below, are repeated to the westward of the Continental divide, in the Swan and Mission ranges, the limestones forming the bigh summits on both ranges (see plate 3). West of the Mission range the lower portion of the Blackfoot series is exposed in the high hills east of Ravalli and Jocko creek. Below the limestones there is a great thickness of siliceous strata, the lowest beds of which were found on Jocko creek, about a mile above Ravalli.

1. Fine grained, quartzitic sandstones of purplish gray and gray color. In the lower portion the purple to purplish gray form bands of color. and above the gray and then the purplish tints predominate.................

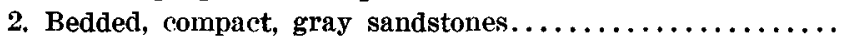

3. Greenish gray, fine grained, compact, quartzitic sandstones, in layers 4 inches to 2 feet thick, with an occasional bed of shaly sandstone $\ldots \ldots \ldots \ldots \ldots \ldots \ldots \ldots \ldots \ldots$.

Feet Feet

Résumé

1. Purple and gray beds........................

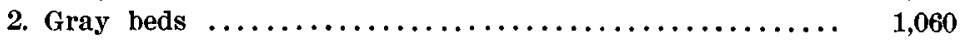

3. Greenish gray beds $\ldots \ldots \ldots \ldots \ldots \ldots \ldots \ldots \ldots \ldots \ldots \ldots \ldots, \quad 4,645$

Résumé of Camp Creek, Mission Range section.-The following is a résumé of the Camp Creek, Mission Range section:

Cambrian.

Plane of unconformity.

Algonkian, Belt terrane.

Camp Creek series $\ldots \ldots \ldots \ldots \ldots \ldots \ldots \ldots \ldots \ldots \ldots \ldots, \quad \mathbf{1 1 , 7 0 0}$

Blackfoot series.....................

Ravalli series $\ldots \ldots \ldots \ldots \ldots \ldots \ldots \ldots \ldots \ldots \ldots \ldots \ldots, \quad \mathbf{8 , 2 5 5}$ 


\section{DEARBORN RIVER SECTION}

Location of the section.-This section is on the south side of the ridge south of the north fork of Dearborn river and 35 miles southeast of the Camp Creek section. It is 10 miles north of the Lewis and Clark pass.

The section begins about 2 miles up the slope below the base of the Flathead Cambrian sandstone, and extends eastward to the gravels at the foot of the mountain slope, a short distance west of the ranch house of Steinbach and Alt.

Cambrian, Flathead sandstones.-The Cambrian Flathead sandstone is massive, coarse grained, with small, white quartz pebbles, and crossbedded near base. Two hundred and fifty-five feet from the base it is overlain by thin bedded sandstones and shales, with numerous annelid trails and fragments of trilobites. The Flathead sandstone rests unconformably upon the Algonkian (see page 16).

Algonkian, Belt terrane.-The following is the Algonkian section exposed on the north fork of the Dearborn river:

1a. Gray, buff weathering, arenaceous, thin bedded layers, passing into greenish gray beds 65 feet from the top...

Feet Feet

b. Cryptozoan, siliceous limestone...................

c. Thin bedded, hard, gray sandstone weathering buff and gray, with greenish tints.................... 205

d. Buff colored, arenaceous shale................. 76

2. Buff weathering, gray, slightly siliceous limestone in shales and layers up to a foot in thickness. Massive layers of interformational conglomerate, composed of broken up, shaly, and thin bedded, bluish gray limestone, oceur 180 feet from the top and bluish gray layers extend below for 25 feet. Oolitic layers occur at several

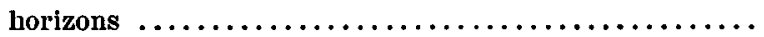

$3 a$. Greenish, arenaceous shales, with thin, interbedded sandstones at irregular intervals. At about 500 feet from the top alternating bands of greenish and purplish, arenaceous shale begin, and continue for some distance before giving way to purple colored, siliceous layers, and thin bedded, fine grained sandstone and purple

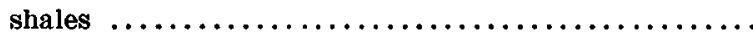

Strike of strata near base, north 40 degrees west, magnetic; dip 25 degrees southwest, near. About 1,000 feet from base, same strike, dip 30 degrees southwest. 
b. Light gray and greenish, siliceous beds in layers and shaly bands. Alternating bands of arenaceous, shaly, and thin bedded sandstones and compact, siliceous, banded layers, flint-like in appearance, occur throughout this part of the series. At 455 feet from the top a sill of dark, eruptive rock, 35 feet thick, outcrops, and 17 feet above, 3 feet of dark, siliceous, hard shale. Mud cracks occur at many lorizons.................

r. Purple, arenaceous shales with occasional thin bands of greenish shale. In the upper part the greenish shales predominate, with occasional bands of purple shales... Dip 45 degrees southwest.

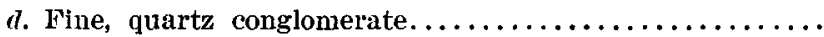

e. Shaly and thin bedded, siliceous and arenaceous shales. They are purple colored in the upper 245 feet and with ocensional purple bands in greenish shales below.

At 300 feet from the top a bed of eruptive rock 25 feet thick occurs and another 5 feet thick 435 feet below.

Dip 30 degrees near base and 40 degrees near top of $3 e$.

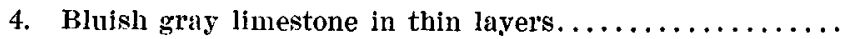

\section{Résumé}

1a-rl. Gray and greenish gray, siliceous and arenacenus beds.. $\quad \mathbf{5 1 0}$

2. Gray, siliceous limestone................... 485

$3 a-e$. Greenish and purple, siliceons and arenaceous beds.... 5,757

4. Gray limestone $\ldots \ldots \ldots \ldots \ldots \ldots \ldots \ldots \ldots \ldots \ldots \ldots \ldots, 15$

The upper portion of this section, $1 a-d$ and 2 , appears to belong to the Blackfoot limestone series, and the beds below to the Ravalli series of the Camp Creck, Mission Range section.

The Cambrian beds are cut off by a fault just above the Flathead sandstones, which brings up gray, arenaceous shales and sandstones of the Algonkian, and above these, brownish red beds corresponding to the Spokane shales of the Lewis and Clark Pass section. 'The latter are capped by the coarse sandstone of the Cambrian Flathead foimation.

\section{LETIS AND CLARK PASS SECTION}

Iocation of the section.-This section is about 10 miles south of that south of the north fork of the Dearborn river.

Cambrian, Flathead sandstones.--The divide at the Lewis and Clark pass trends northeast and southwest. The massive bedded, coarse sand-

1I-Buld. Grol. Soc. AM., Yol, 17, 1905 
stones of the Cambrian Flathead formation form the northwest side and the reddish brown sandstones and shales of the Algonkian Belt terrane the southeastern side, the Algonkian lying unconformably below the Cambrian.

Algonkian, Belt terrane.-The Algonkian at the Lewis and Clark pass comprises the Marsh, the Helena, and the Empire formations, as follows:

\section{Marsh formation}

1. Reddish brown, arenaceous shales and sandstones, simllar to the Marsh shales of the Belt terrane..............

2. Gray, hard, arenaceous shales and sandstones, with alternating bands of reddish brown, thin bedded and shaly sandstones, 20 to 40 feet in thickuess..............

Feet Feet

\section{Helena formation}

Thin bedded, gray, siliceous linestone, with numerous arenaceous layers in the upper 25 feet. The central and lower portions have interbedded, bluish gray limestone with occasional layers of interformational conglomerate, formed of thin, shaly limestones. The siliceous, hard layers weather a yellowish buff color..........

\section{Empire formation}

Gray, arenaceous shales and thin bedded sandstones. $A$ bed of Cryptozoan limestone two feet thick occurs near the top and a similar bed 360 feet below..............

\section{Résumé of Algonkian, Belt terrane}

Marsh formation:

1. Reddish brown, arenaceous shales and sandstones........

2. Gray, arenaceous shales and sandstones............ 225

Helena formation:

Gray siliceons limestones $\ldots \ldots \ldots \ldots \ldots \ldots \ldots \ldots \ldots \ldots, \quad \mathbf{2 8 5}$

Empire formation:

Gray, arenaceous shales and sandstones............ $\mathbf{1 , 2 1 0}$

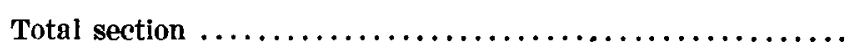

\section{SWAN RANGE SECTION}

Location of the section.-The section of the limestones and interbedded siliceous strata of the Swan range, south of Holland peak, begins beneath the red sandstones of the Camp Creek series and extends westward, over the crest of the range, nearly to its western base. 
Algonkian.-The red and gray arenaceous beds of the Camp Creek series form the top of the Algonkian section in the Swan range, and overlie the limestones of the Blackfoot series.

\section{Blackfoot series-Upper division}

Feet Feet

1a. Banded, siliceous or cherty layers predominate at the top, with a few thin layers of gray limestone and shaly. arenaceous layers 6 to 15 inches thick..............

b. Gray, thin bedded limestones, with intercalated cherty layers $\ldots \ldots \ldots \ldots \ldots \ldots \ldots \ldots \ldots \ldots \ldots \ldots \ldots \ldots . \ldots \ldots$

2a. Gray, banded chert, with a dark bluish black layer 2 feet thick near the top $\ldots \ldots \ldots \ldots \ldots \ldots \ldots \ldots \ldots \ldots \ldots$.

b. Gray, thin bedded limestone, weathering buff, somewhat shaly in the upper 600 feet and more distinctly bedded below

c. Alternating cherty beds and grayish limestone, with the cherty beds predominating in the upper portion.......

Near the base there is a layer three feet in thickness almost entirely made up of massive specimens of Cryptozoan.

d. Gray, thin bedded cherty beds.

$e$. Gray, rough, siliceous, and arenaceous limestone in thick

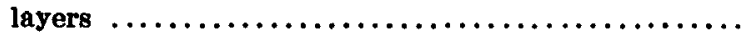

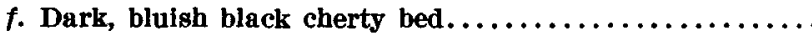

g. Gray, rough, siliceous, and arenaceous limestone layers 2

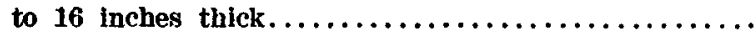

About 50 feet from the summit numerous specimens of Cryptozoan occur in a bed about 6 inches in thickness.

Total of Upper division.

\section{Blackfoot series-Lower division}

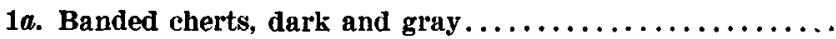

b. Gray, compact, more or less siliceous limestone, with cherty layers and irregular nodules that correspond in form to the calcareous nodules in $1 f . \ldots \ldots \ldots \ldots \ldots$.

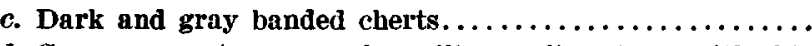

d. Gray, compact, more or less siliceous limestone, with thin cherty layers and irregular nodules similar to the

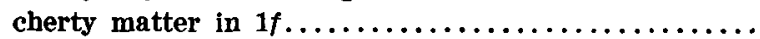

$e$. Banded, cherty beds, with small amount of calcareous matter in the form of nodules and irregular thin layers

f. Siliceous and calcareous layers, from one-half to 2 inches in thickness. The ealcareous matter is in the form of 
irregular, bluish gray, limestone nodules, imbedded in a siliceous matrix. Sometimes the siliceons matter, and sometimes the calcareous, predominates, and occasionally layers that are purely siliceous. or arenaceous limestone, occur, and banded, cherty layers are of frequent occurrence. Occasionally the nodules of limestone are small, very irregular in size and form, and almost make up the entire mass of the rock, the siliceous matter simply holding them together...........

g. Light gray, cherty, siliceous, banded beds, 1 to 2 feet in thickness, with partings of siliceous shale at irregular intervals. Layers occur with numerous flattened bluish gray, limestone nodules and stringers arranged parallel to the bedding. Some of the shaly beds are 1 to 2 feet in thickness and more or less argillaceous or calcareous. On the weathered surface the calcareons beds weather buff and dull gray. Seventy feet below the top there is a band of arenaceous, gray shale 35 feet in thickness...

The section was all carefully measured, with the exception of the lower 600 feet, which was estimated from dip and occasional outcrops on the lower slopes of the ridge.

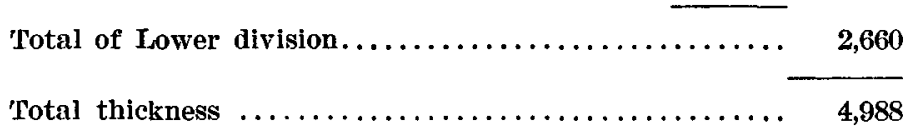

The Upper division contains more calcareous matter, and the Lower division is more siliceous. The separation is somewhat arbitrary, and probably would not hold good at any considerable distance from where the section was measured.

The general strike of the beds of the section is north 30 degrees west; average dip, 35 degrees north.

\section{NOTES ON SECTION FROM BELTON, EAST}

Bad Rocks Canyon section.--During September, 1895, I made a rapid trip along the line of the Great Northern Railroad track from Belton to the vicinity of Essex, and thence north to the head of Nyack creek.

In Bad Rocks canyon, Montana, on the line of the Great Northern railroad, the section given below was measured. This portion of the section appears to correspond with the Blackfoot limestone of the Mission Range section, 85 miles to the south, and to indicate that that horizon is persistent on the line of the strike of the Mission and Swan ranges. The section is as follows: 
Descending series.

1. Banded blue and gray arenaceous limestone................ 700

2. Dark bluish limestone in massive beds.................. 650

3. Greenish colored limestone, impure and with many small calcare-

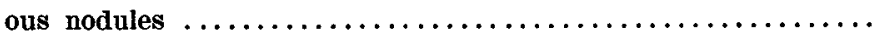

4. Dark bluish limestone (similar to number 2 ) $\ldots \ldots \ldots \ldots \ldots \ldots$

5. Greenish, banded, massive argillaceous limestone........... 2,000

6. Alteruating green and purple argillaceous beds, massive layers

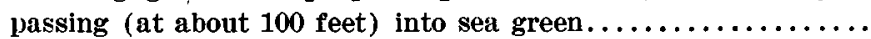

6a. Green, passing down into purple (same as number 6) ........ 350

No fossils; no well defined base or summit.

In the notes taken at the time the following occur:

At Belton greenish shales and massive beds of calcareous argillite-like rock dip northerly about 40 degrees. Bluish and banded limestones come in on top of the greenish beds. The limestones are in heary beds, 2 to 4 feet thick, and quite pure in some layers. No traces of life with the exception of a Stromatopora-like form. The strike and dip of the beds vary; but the section appears to be practically unbroken and to consist of a portion of the "Castle Mountain group" of McConnell. The raiirroad curves in and out along the strike, following the bends of the Middle fork of the Flathead river. About 7 miles from Belton some reddish beds of calcareous argillite appear along with the greenish beds. There may be 2,000 to 3,000 feet of the limestone.

It will be noted that at the time I thought that this series probably represented a portion of the Castle Mountain group of McConnell. Reference will be made later to this (see page 22 ).

The notes further state:

One mile and a half east of Paola the red shales (calcareous argillite) appear in a railroad cut. Strike, north 80 degrees west (magnetic); dip, north 30 degrees.

The red and green beds extend east of Essex to Java, where massive bluish limestones appear. In cuts between Java and Bear creek is the limestone. Strike, east and west (magnetic); dip, 20 degrees north. The rocks are evidently the massive Castle Mountain limestones of McConnell. The general strike swings to north 60 degrees east, and the dip decreases to 15 degrees north. Two miles west of Bear creek a syncline and fault occurs that brings up the green and red beds beneath the limestone.

Nyack Creek section.*-At the head of Nyack creek a fine amphitheater is eroded out of the red beds and superjacent calcareous shales and lime-

* Notes were made September 19, 1895. 
stones. The Castle Mountain rocks form fine ridges and peaks along the Rocky Mountain divide for many miles. There is evidently a fault on the east, as the strata rise and end abruptly as far as could be seen. A species of Raphistoma was found in the shaly limestone 2,000 feet or more above the base of the limestones. Only a few hours were available for the study of this most interesting section, as snow began falling and continued until it was several feet in depth.

This note indicates the presence of the upper red beds of the Camp Creek Algonkian series, with the Cambrian and Ordovician strata above.

GENERALIZED SECTION, CEEUR D'ALENE DISTRICT, IDAHO

The following is a generalized tabular section of Algonkian rocks in the Cceur d'Alene district of Idaho, prepared by Mr F. C. Calkins:

\begin{tabular}{|c|c|c|c|}
\hline No. & Name. & Description. & $\begin{array}{l}\text { Thick- } \\
\text { ness } \\
\text { in feet. }\end{array}$ \\
\hline 6 & $\begin{array}{l}\text { Striped Peak for- } \\
\text { mation. }\end{array}$ & $\begin{array}{l}\text { Sandstones, siliceous, generally flaggy to } \\
\text { shaly; colors mostly green and purple; } \\
\text { characterized by shallow-water features, as } \\
\text { ripple marks, sun cracks, etcetera. }\end{array}$ & $1,000+$ \\
\hline 5 & $\begin{array}{l}\text { Wallace forma- } \\
\text { tion. }\end{array}$ & $\begin{array}{l}\text { Thin bedded sandy shales, underlain by } \\
\text { rapidly alternating thin beds of argillite, } \\
\text { calcareous sandstone, impure limestone, and } \\
\text { indurated calcareous shale; these underlain } \\
\text { in turn by green siliceous argillites; shal- } \\
\text { low-water features throughout; slaty cleav- } \\
\text { age common. }\end{array}$ & $2,500+$ \\
\hline 4 & $\begin{array}{l}\text { Saint Regis for- } \\
\text { mation. }\end{array}$ & $\begin{array}{l}\text { Sandstones, generally flaggy or shaly; usually } \\
\text { fne grained and much indurated ; colors } \\
\text { mostly green and purple; characterized by } \\
\text { shallow-water features. }\end{array}$ & 800 \\
\hline 3 & Revett quartzite. & $\begin{array}{l}\text { White quartzites, generally rather thick } \\
\text { bedded; interstratified with subordinate } \\
\text { quantities of micaceous sandstone. }\end{array}$ & 1,000 \\
\hline 2 & Burke formation.. & $\begin{array}{l}\text { Gray, flaggy, fine grained sandstones and } \\
\text { shales, with interbedded purple quartzitic } \\
\text { sandstone (the proportion varies widely in } \\
\text { different parts of the district) and white } \\
\text { quartzite; the formation characterized } \\
\text { throughout by shallow-water features. }\end{array}$ & 1,700 \\
\hline \multirow[t]{2}{*}{1} & \multirow[t]{2}{*}{ Prichard slate... } & \multirow{2}{*}{$\begin{array}{l}\text { Mostly blue black, blue-gray to light gray } \\
\text { slates, generally distinctly banded; consid- } \\
\text { erable interbedded gray sandstone; upper } \\
\text { portion characterized by rapid alternations } \\
\text { of argillaceous andarenaceous layers, and by } \\
\text { shallow-water features; base not exposed. } \\
\quad \text { Total................................ }\end{array}$} & $8,000+$ \\
\hline & & & 15,000 \\
\hline
\end{tabular}




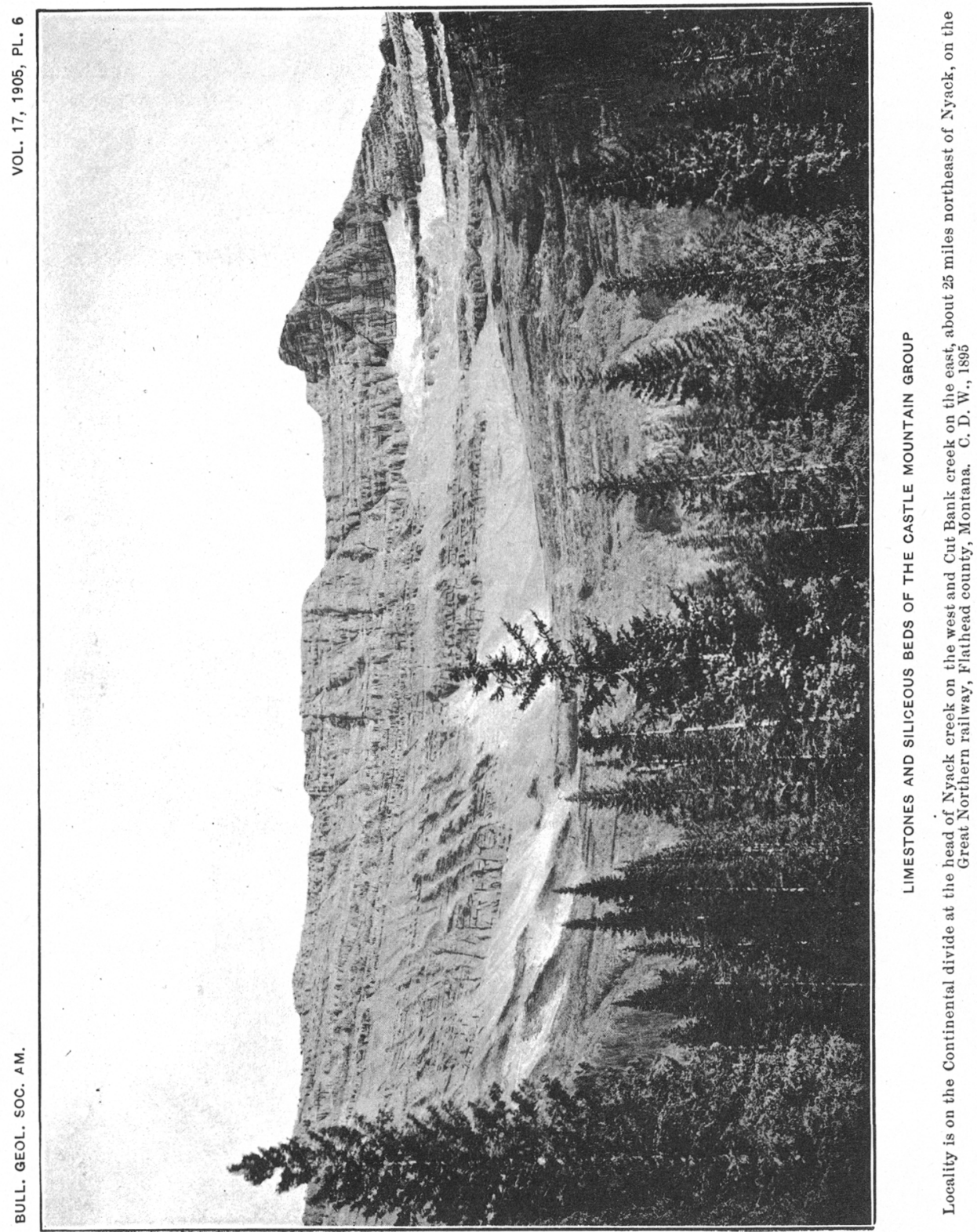


. 
GENERALIZED SECTION FROM STRIPED PEAK, ID.AHO

The following is a generalized section of A]gonkian rocks from Striped peak, north and northeast of the Cœur d'Alene district, Idaho, prepared by Mr F. C. Calkins:

\begin{tabular}{|c|c|c|c|c|}
\hline \multicolumn{2}{|c|}{ Formation down. } & \multirow{2}{*}{ Description. } & \multirow{2}{*}{$\begin{array}{l}\text { Approximate } \\
\text { thickness. }\end{array}$} & \multirow{2}{*}{ Remarks. } \\
\hline No. & Name. & & & \\
\hline 5 & $\begin{array}{l}\text { Striped Peak for- } \\
\text { mation. }\end{array}$ & $\begin{array}{l}\text { Sandstones and shales, } \\
\text { siliceous, purple, red, } \\
\text { and green, with shallow- } \\
\text { water features. }\end{array}$ & $2,000+$ & Near Heron \\
\hline 4 & $\begin{array}{l}\text { Wallace forma- } \\
\text { mation (equiv- } \\
\text { alent to Daly's } \\
\text { Moyie argillite). }\end{array}$ & $\begin{array}{l}\text { Argillites, generally cal- } \\
\text { careous, blue gray and } \\
\text { greenish gray, with thin } \\
\text { beds of calcareous quart- } \\
\text { zite and impure lime- } \\
\text { stone; general composi- } \\
\text { tion becoming more cal- } \\
\text { careous eastward. }\end{array}$ & $5,000 \pm$ & $\begin{array}{l}\text { No complete } \\
\text { section. }\end{array}$ \\
\hline 3 & $\begin{array}{l}\text { Burke-Saint Re- } \\
\text { gis formation } \\
\text { (equivalent to } \\
\text { Daly's Kitch- } \\
\text { ener quartzite). }\end{array}$ & $\begin{array}{l}\text { Shaly indurated siliceous } \\
\text { fine grained sandstones } \\
\text { and quartzites; colors } \\
\text { gray, greenish, and pur- } \\
\text { plish; some hard white } \\
\text { quartzite in Cabinet } \\
\text { mountains equivalent to } \\
\text { Revett quartzite of Cour } \\
\text { d'Alene district. }\end{array}$ & $8,000 \pm$ & \\
\hline 2 & Prichard slate.... & $\begin{array}{l}\text { Banded dark slates, blue } \\
\text { black, blue gray to light } \\
\text { gray, with some inter- } \\
\text { bedded gray quartzite. }\end{array}$ & $\begin{array}{l}10,000 \pm \text { to } \\
\text { zero. } \\
2,000 \text { near } \\
\text { Idaho-Mon- } \\
\text { tana bound- }\end{array}$ & $\begin{array}{l}\text { Thickness east- } \\
\text { ward not rec- } \\
\text { ognized by } \\
\text { Daly. }\end{array}$ \\
\hline 1 & $\begin{array}{l}\text { Creston quartzite } \\
\text { (Daly). }\end{array}$ & $\begin{array}{l}\text { Gray, more or less flaggy } \\
\text { quartzites, with argilla- } \\
\text { ceous bands. }\end{array}$ & $9,900+$ & $\begin{array}{l}\text { Daly's figure. } \\
\text { Probably thins } \\
\text { out eastward. }\end{array}$ \\
\hline
\end{tabular}

N. B. -Ripple marks, sun cracks, etcetera, abundant in all formations but Prichard and Creston.

\section{NOTE ON LIMESTONES NEAR KALISPELL}

Massive bedded, drab, light colored limestone, breaking up on weathering into shaly layers in some of the beds and in others into irregular fragments with a conchoidal fracture. A few layers of shaly limestone with some arenaceous interbedded layers occur in the series. Near the town, at the quarry, there is about 300 feet in thickness of the limestones exposed. They dip south at an angle of 5 to 10 degrees. The limestones 
cover a wide area to the west and south and are apparently interbedded in the quartzite series exposed on the line of the Great Northern railroad to the westward, on the ridge cut through at Haskell pass. Up to date this series may be referred to the Algonkian, although this is probably the same as Dawson's Cambrian to the north, in British Columbia.

These limestones appear to be a portion of the Blackfoot Limestone series of the Mission range.

\section{Unconformity between Algonkian and Cambrian}

I have described the unconformity existing between the strata of the Belt terrane and the Cambrian in the Big Belt mountains and in the vicinity of Helena. It was found that in one instance upward of 3,000 feet of Algonkian beds had been removed by pre-Cambrian erosion, and that it was exceptional to find the same Algonkian strata in contact with the Cambrian in localities a few miles distant from each other.* We find similar conditions as the contact of the two systems of strata is traced to the west and northwest. At Lewis and Clark pass the Cambrian rests on a series of reddish brown sandstones, 1,015 feet in thickness, above the Helena calcareous beds. At Helena, 40 miles distant, there are 70 feet of similar sandstones between the Cambrian and the Helena limestone. At the Dearborn section, 10 miles north of Lewis and Clark pass, the Cambrian rests on siliceous and calcareous strata that appear to belong to a portion of the Algonkian section 1,000 feet or more beneath the horizon in contact with the Cambrian at Lewis and Clark pass. ' In the vicinity of Scapegoat mountain, 35 miles northwest, the Cambrian is superjacent to a series of gray sandstones and shaly beds, 1,700 feet thick, that do not appear to be represented in the Dearborn section.

No contacts with the Cambrian have been observed west of the ridges between the north fork of the Flathead river and the Swan range, although from the presence of Cambrian fossiliferous limestones west of the Mission range such contacts may be found.

Eighty miles north of the Scapegoat area, in the vicinity of Cut Bank pass, at the head of Nyack creek, it is difficult to locate the line of demarcation between the fossiliferous limestones and the Algonkian strata, 2,000 feet below. Further study is needed in this area.

One hundred miles farther north the section appears to be conformable from the Ordovician down through the Middle Cambrian and the Lower Cambrian of the Bow River series, and not to reach down to the Algonkian as it occurs in Montana, the Bow River series being the sediment

* Loc. cit., pp. 210-215. 
deposited, in part at least, in the erosion interval between the Algonkian and the Middle Cambrian.

\section{Correlation of Shctions}

The most easterly section, that of the Belt mountains, has more limestone in proportion to the arenaceous matter and, with the exception of the Neihart sandstone at the base, finer sediments; these conditions indicate that the sediments were derived mainly from a somewhat distant source of supply. One horizon of this section, the Newland limestone, is marked by the presence of fossil crustaceans that also occur in the sections $200^{\circ}$ miles to the northwest, as discovered in the Lewis range by Messrs Willis and Weller,* and Doctor R. A. Daly on the forty-ninth parallel. $\dagger$

Tracing the upper formations of the Belt terrane north of Helena, we find, at Lewis and Clark pass on the Continental divide, a series of reddish, arenaceous rocks beneath the Cambrian, with some limestone. This is 40 miles from the typical section east of Helena, and there is a manifest change in the sediments, especially in the presence of a greater thickness of arenaceous beds between the base of the Cambrian and the Helena. limestone. At Helena the Marsh shales are 300 feet thick, and similar beds at the Lewis and Clark pass give a thickness of 1,015 feet.

The Helena Limestone series in the vicinity of Helena has an estimated thickness of 2,400 feet. It has numerous arenaceous and siliceous bands interbedded with the limestone. By the elimination of a relatively small amount of the calcareous matter the greater part of the limestones would disappear, and a section much like that of Lewis and Clark pass replace the Helena Limestone series.

Ten miles north of the Lewis and Clark Pass section the limestones of the Dearborn section corresponding to those of the Helena series are well developed. The reddish colored shales of the Marsh formation appear to be absent, the Cambrian resting on buff and gray arenaceous beds below the reddish beds of the Liewis and Clark Pass section. The Helena limestone series is represented by 435 feet of siliceous limestones. Below the latter a great thickness of greenish and purplish tinted arenaceous and siliceous beds extend downward 5,700 feet before any more

\footnotetext{
*Bull. Geol. Soc. Am., vol. 13, p, 317.

f Doctor Daly writes me that the locality is at a point on Oil creek about 6 miles east of the Boundary monument at the summit of the Rocky mountains and about 4 miles north of the line. Through the courtesy of the Geological Survey of Canada, by Doctor Daly, I had the opportunity of examining the specimens. They are identical in appearance and form with those from the Newland and Altyn formations.
}

I1I-Buhr. GeoL. SOC. AM., Vor. 17. 1905 


\section{Algonkian Sections of Northwhestern Montana and Northern Idaro}

TEE PRINCIPAL HORIZON FOR CORRELATION IS. THE FOSGILIFEROUS NEWLAND LIMEETONE OF THE BELT KOUNTAINS SECTION

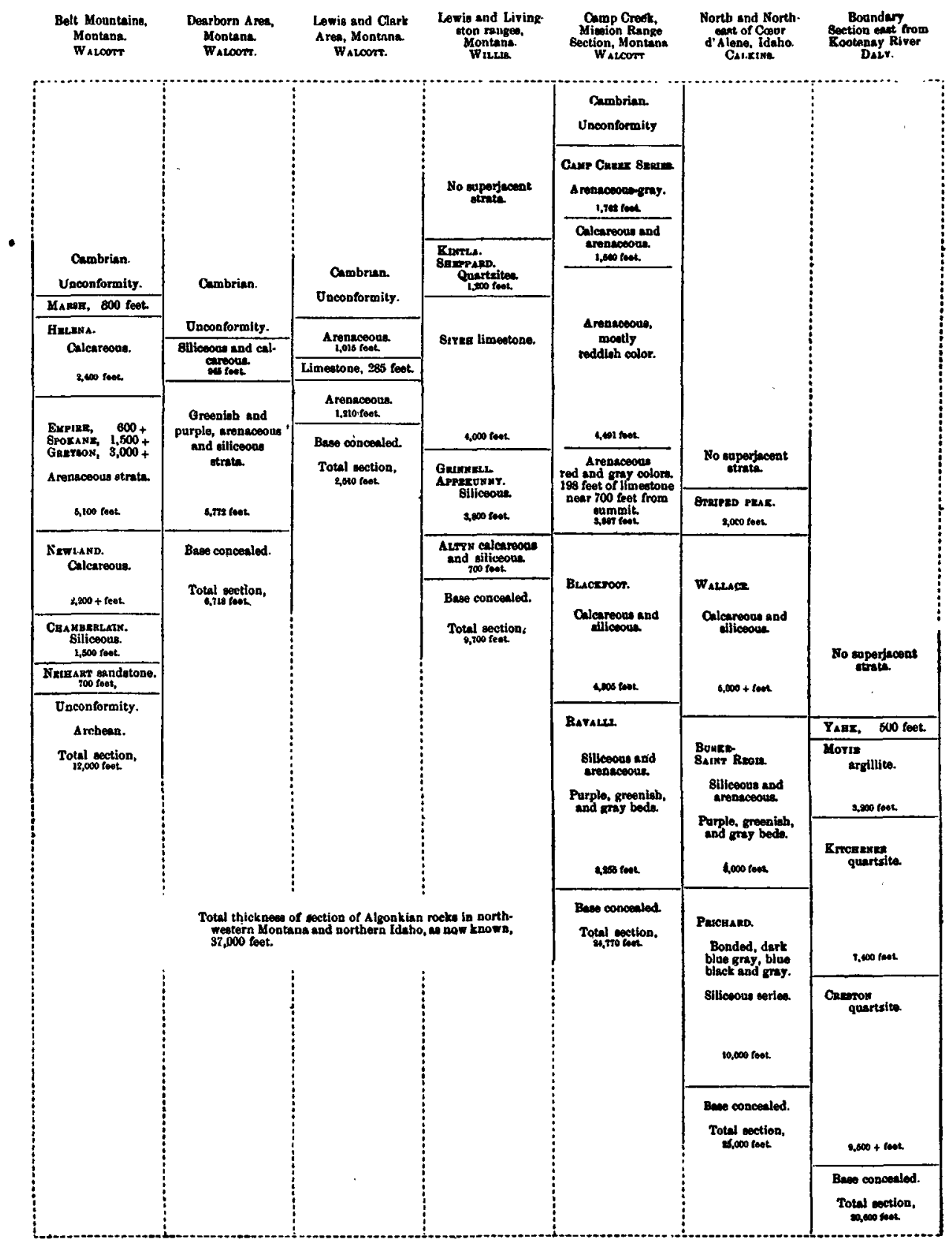


limestone occurs. This series corresponds to the 5,100 feet of the Empire, Spokane, and Greyson strata of the Belt Mountains section above the Newland limestone. Only the top beds of the latter occur at the base of the Dearborn section.

Continuing northward 120 miles Mr Bailey Willis's section of the Lewis range shows a great development of limestone at about the same horizon as the Helena limestone. This, the Siyeh limestone of Willis, has an estimated thickness of 4,000 feet. It is dark blue or grayish, weathering buff, and contains interformational conglomerates and abundant remains of Cryptozoan, a form unknown in the Cambrian and Ordovician rocks of the Rocky mountains, but which is abundant in the limestones of the Algonkian terranes. The presence of Cryptozoan and also the stratigraphic relations described by Willis indicate that the Siyeh limestone is an Algonkian formation. The series of limestones at the head of Nyack creek, illustrated by plate 6 , are of Cambrian or Ordovician age, as indicated by fragments of fossils that I found in them. 1 do not think the Siyeh limestone is to be correlated with them, nor with the Castle Mountain limestones of McConnell.

The Siyeh (Helena) limestone is overlain by 1,500 feet of arenaceous and siliceous beds corresponding to the arenaceous and siliceous beds above the limestone of the Dearborn section.

Subjacent to the Siyeh limestone there is 3,800 feet of highly siliceous and argillaceous rocks (Grinnell and Appekunny) corresponding to the 5,100 feet of beds of the Empire, Spokane, and Grcyson formations of the Belt Mountains section.

The siliceous beds are underlain by the Altyn limestone formation, which by its contained fossils and lithologic characters is identified with the Newland limestone of the Belt Mountains section. Typical fragments of Beltina danai of the Newland limestone occur in the Altyn formation; also Cryptozoan. The Altyn limestone forms the base of the Lewis Range section.

The great Camp Creek, Mission Range section begins at a point 35 miles northwest of the Dearborn section and about 85 miles south of the Lewis Range section of Willis. Its upper portions are marked by a great development of arenaceous beds ( $1 a$ of section) above the Helena limestone horizon of the Belt mountains and the Dearborn section.

Below this upper grayish, arenaceous formation there is a thick belt of reddish brown, arenaceous shales (1,560 feet), with more or less thin bedded limestone, alternating irregularly with the greenish gray bands of shales and sandstones, somewhat as in the Helena limestone series.

This is underlain by 5,191 feet of arenaceous beds, mainly sandstones, 
largely reddish brown in color, with interbedded belts of grayish red and gray sandstones and sandy shales. The section is here interrupted by a band of compact, impure, siliceous and arenaceous gray limestone 198 feet in thickness. The occurrence of this band of limestone and a thin deposit of calcareous Cryptozoan 500 feet below indicates local conditions favorable for the deposition of limestone.

Below the siliceous limestone there is a great series of reddish gray and reddish sandstones 3,089 feet in thickness. This, with the arenaceous beds above the limestone, gives a total thickness of 8,280 feet, which is interrupted only by the one band of siliceous limestone 198 feet in thickness. This series appears to be a great thickening of the Empire, Spokane, and Greyson formations of the Belt Mountains section.*

The next formation below (Blackfoot) is formed of shaly limestones (see plate 3) alternating with thin layers of gray limestone, 2,500 feet of the thickness of which is largely limestone, with some interbedded and incorporated siliceous and arenaceous material. The lower 1,850 feet is largely a highly siliceous limestone with bands of almost purely siliceous material. This limestone series has abundant remains of Cryptozoan. On the North fork of Blackfoot river the central portions of the limestones are much like those of the Newland limestones of the Belt Mountains section, while in the Mission range, where they are somewhat metamorphosed, they present the bold cliffs and hard, massive, flinty layers characteristic of the cliffs of Altyn limestone of the Lewis Range section.

The Blackfoot series appears to be identical in stratigraphic position and character with the Newland limestone of the Belt Mountains section, and the Altyn limestone of the Lewis Range section, and the Wallace calcareous series of the Cœur d'Alene section of Idaho.

Below the Blackfoot there is, west of the Mission range, a series 8,255 feet in thickness of purple, greenish and gray, siliceous, and arenaceous beds, which completes the section measured by me in the season of 1905 . This series, named Ravalli, probably represents that portion of the Coeur d'Alene section between the Wallace and the Prichard series, and it may be a part of the upper portion of the Prichard.

The Cœur d'Alene series does not appear to extend upward to the horizon of the Helena limestone, as there is only 1,000 feet of the reddish beds above the Wallace series which is correlated with the Newland Limestone horizon.

The strata below the Wallace and above the Prichard are correlated with the Ravalli series; and the Prichard, which is composed of dark,

\footnotetext{
* Mr M. Collen, of White Sulphur Springs, Belt mountains, Montana, wrote me in the spring of 1905 that he had found a marked unconformity between the Greyson shales and the Newland limestone on Birch creek.
} 


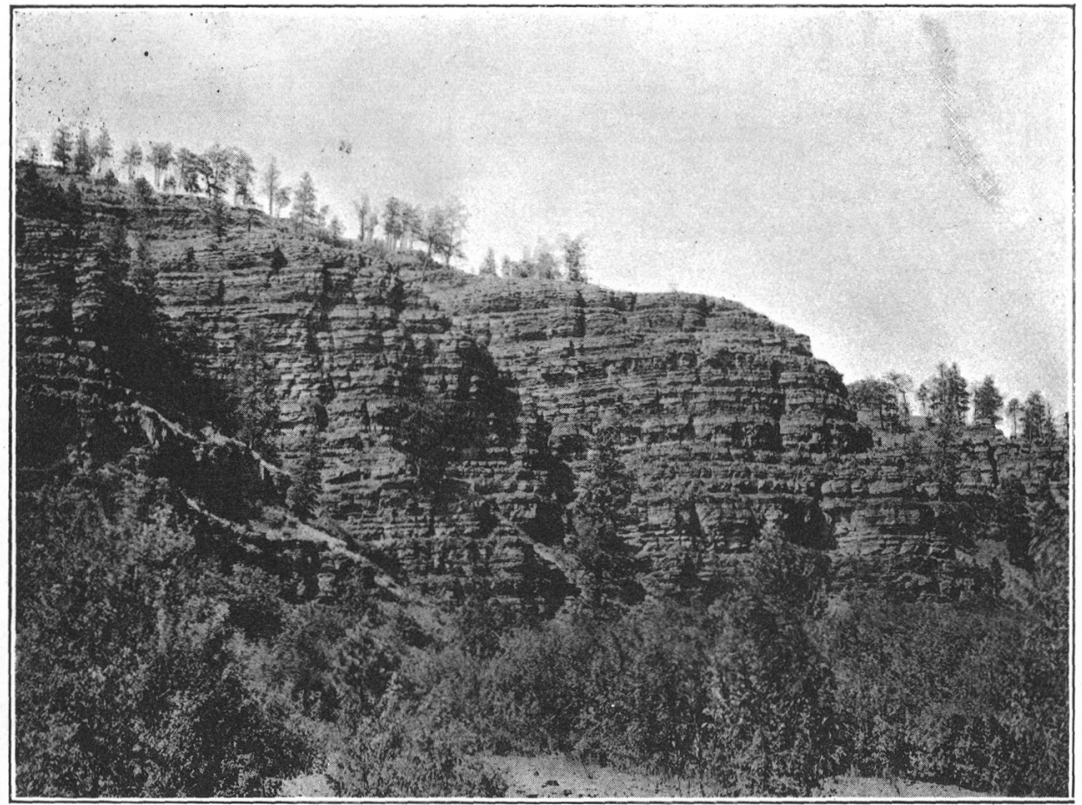

Fiqure 1.-Ch.iff of typical, banded, arenaceors and siliceous Shates of Spokane Formation Belt terrane, on Wolf creek, 2 miles below Mitchell, Big Belt mountains, Montana. C. D. W., 1900

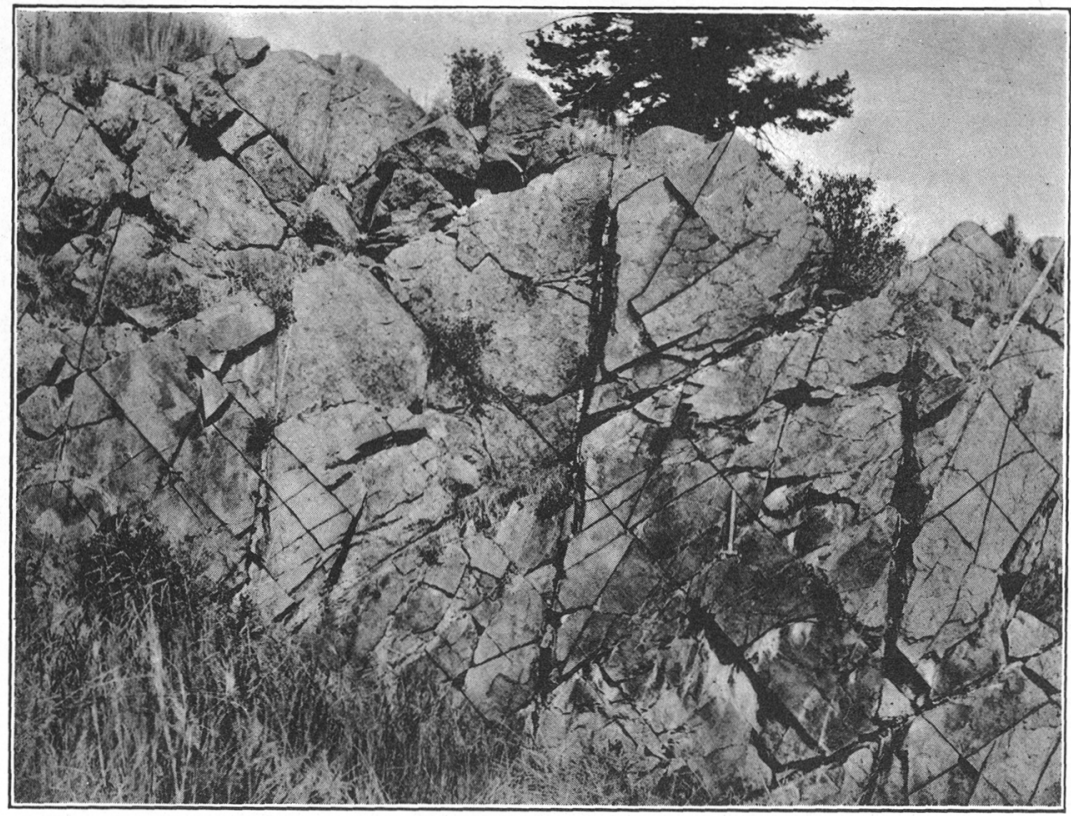

Figure 2.-Surface of Upturned Beds of QuartztT

Three systems of jointing are shown. Greyson shales, Belt terrane, Deep Creek canyon, 14 miles east of Townsend, Big Belt mountains, Montana. C. D. W., 1898 
BULL. GEOL. SOC. AM.

VOL. 17, 1905, PL. 8

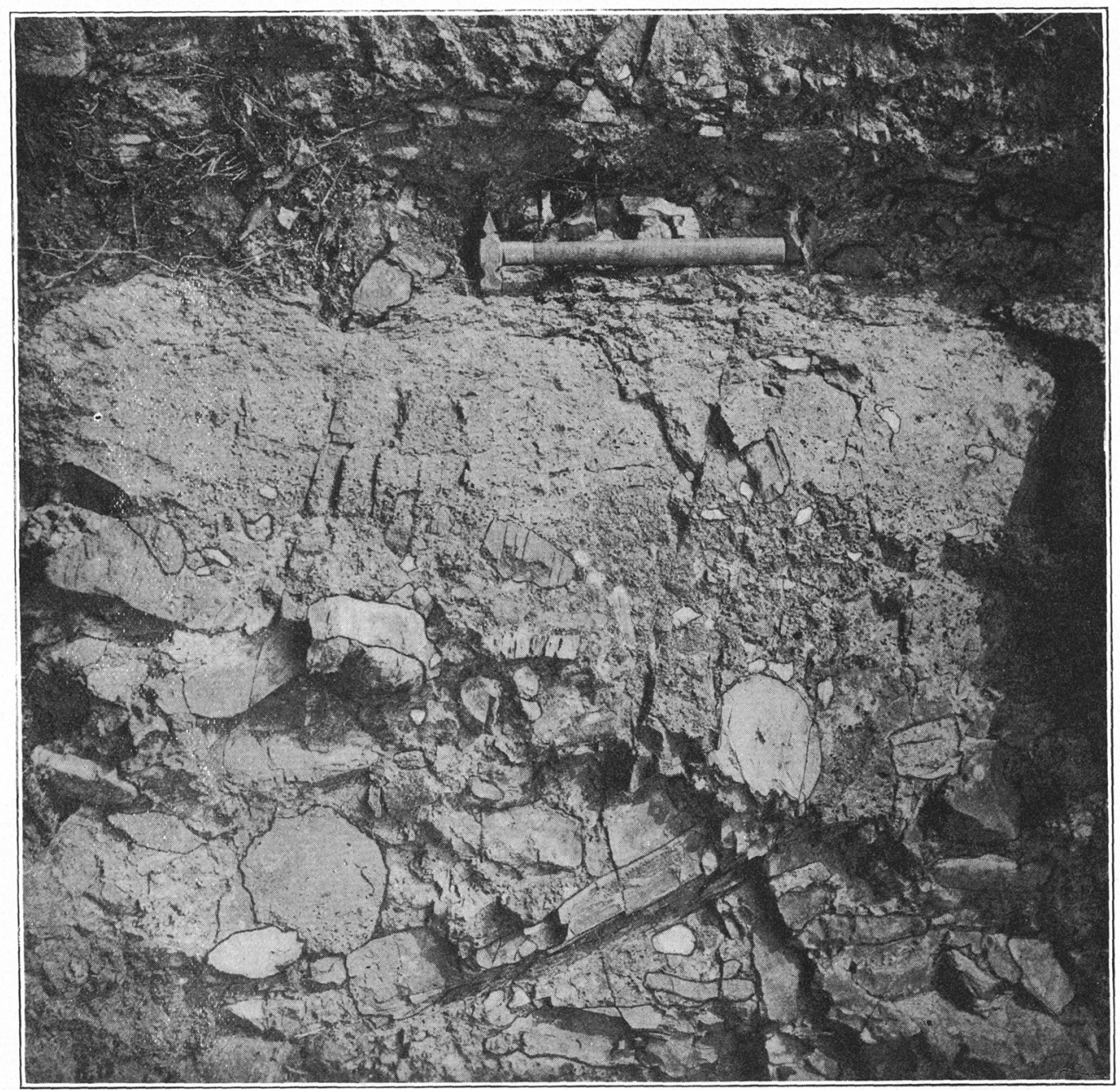

CONGLOMERATE NEAR BASE OF GREYSON SHALES

Belt terrane, Deep Creek canyon, 1 mile east of Townsend, Big Belt mountains, Montana. Indicates unconformity between Greyson shales and Newl:and limestone. C. D. W., 1898 


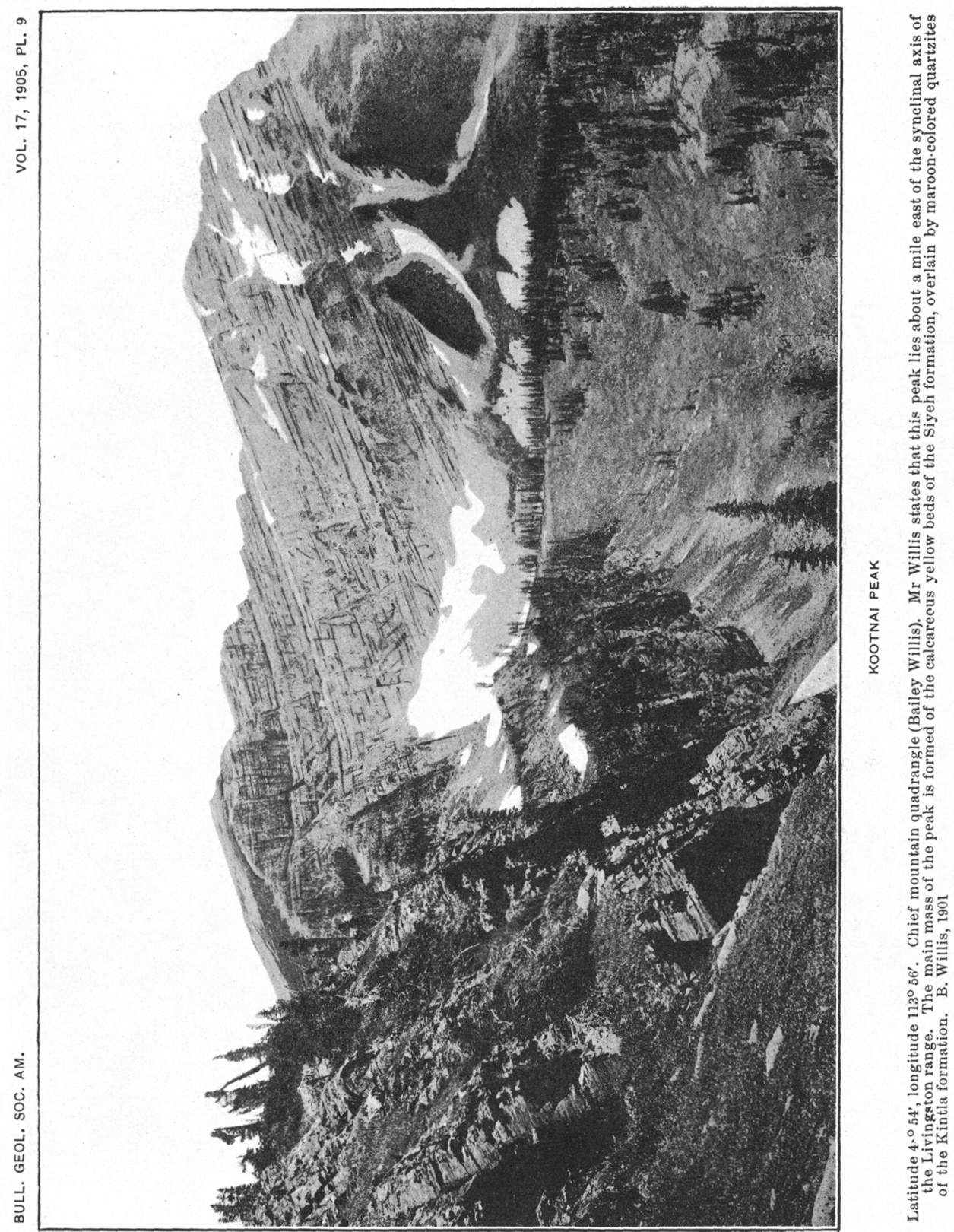




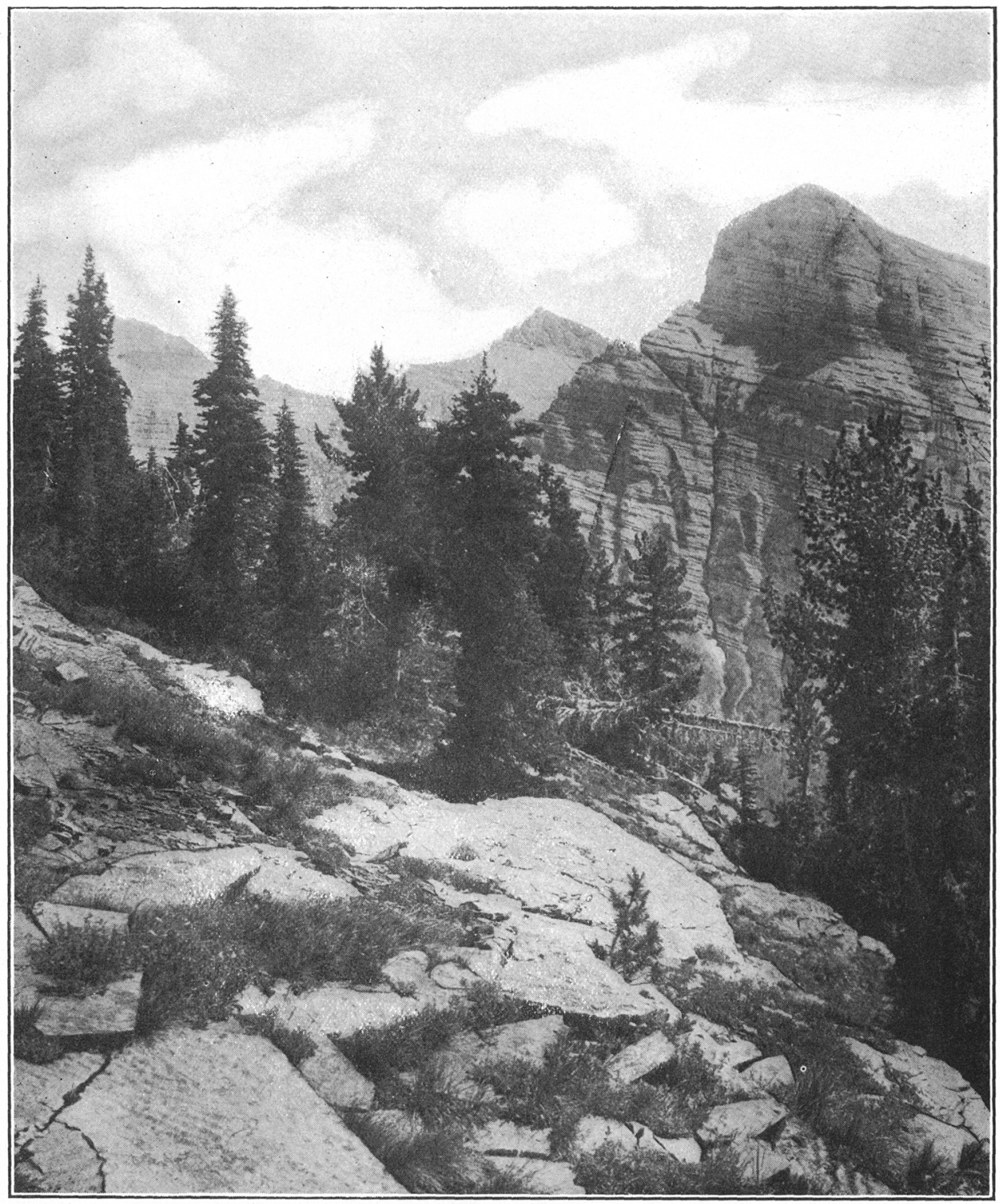

SIYEH LIMESTONE

General view of the banded phase of the limestone, with ripple-marked slabs of limestone in the foreground. Little Kootna creek, Chief Mountain quadrangle, Montana. B. Willis, 1901 


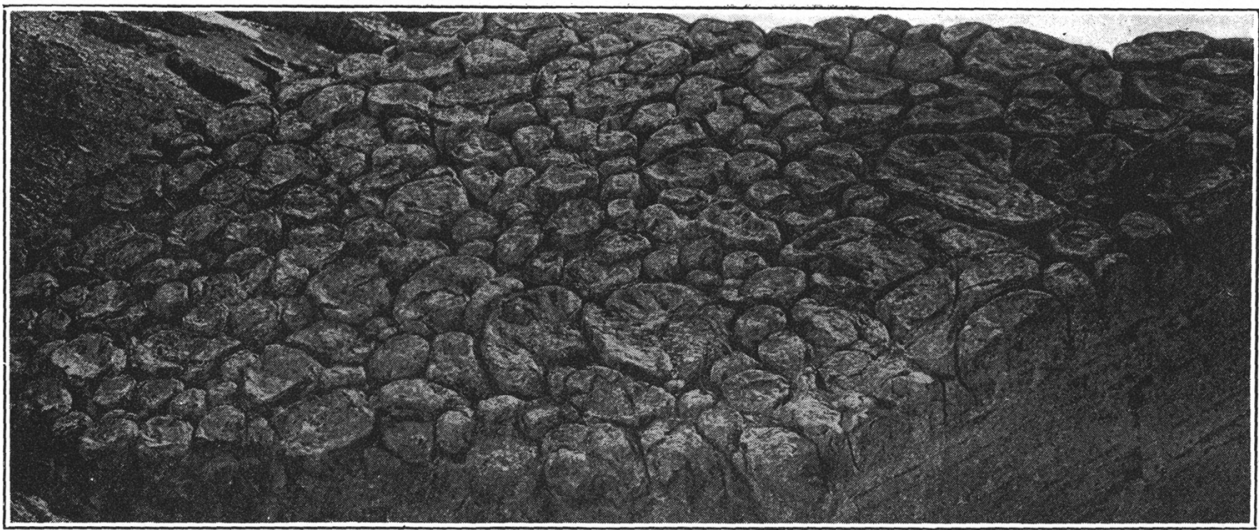

Figure 1.-Upper Surface of a Group of Spectmens of Cryptozoanfiequens (n. sp.) on a Block of Siyeh Limestone. BaIley Willis

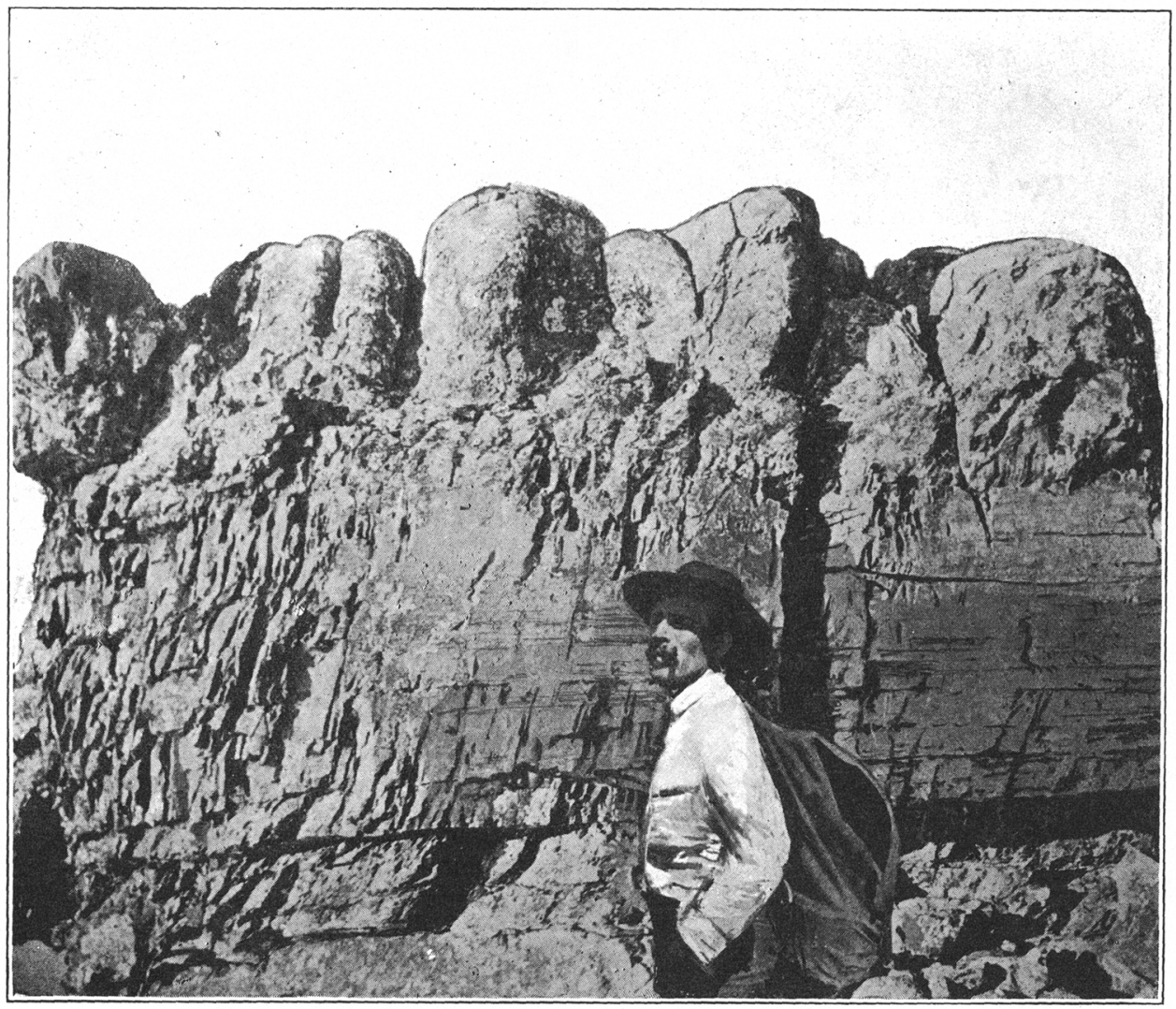

Figure 2.-Side View of Block represented in Figure 1, showing Meithod of Growth of Cryptozoan frequens BaILEY Wilits 

shaly, and thin bedded siliceous rocks, with the Chamberlain shale horizon of the Belt Mountains section.

The various correlations outlined are represented in graphic form on the table, the horizon of the upper limit of the Newland limestone, at which the crustacean fauna appears, being taken as the horizon from which to correlate the various sections. Of the sections mentioned all but the Lewis Range, Cour d'Alene, and Kootenay sections are overlain by unconformable Middle Cambrian formations. Only one section, the Belt mountains, has been observed with its base in contact with the Archean.

\section{Correlation of Montanian with Canadian Sections}

Mr Bailey Willis has shown the intimate relations between the Boundary section of Dr George M. Dawson and the section studied by him, crossing the Lewis and Livingston ranges.* The formations described by Doctor Dawson are the northward extension of those named by $\mathrm{Mr}$ Willis.

The section of Mr R. G. McConnell, across the "Rocky mountains" near the fifty-first parallel, includes the Bow River series and the Castle Mountain group. The latter is a great series of massive bedded, dolomitic limestones, below becoming more shaly, and calcareous above. The included fossils prove the lower portions to be Cambrian and the upper of Ordovician age.

Of the Bow River series Mr McConnell says : $\uparrow$

"Ihe Bow River group forms the basal nember of the section in this part of the mountains, and, as developed along the line of railway, consists mainly of a great series of dark-colored argillites, associated with some sandstones, quartzites and conglomerates. The base is not seen, but the part exposed has an estimated thickness of 10,000 feet.

"The argillites are usually dark grayish in color, but become greenish and purplish in places, are very impure, and frequently grade into flaggy sandstones, which are often slightly calcareous.

"The conglomerates characterize more especially the top of the formation, and occur in thick, massive looking bands, alteruating with quartzites and shales. They are usually firmly cemented into a hard, unyielding rock, but are also met with in a little consolidated and crumbling condition.

"The quartzites, like the conglomerates, are mostly found in the upper part of the formation, and sometimes, as in Cathedral mountain, replace the latter altogether.

* Bull. Geol. Soc. Am., 1902, vol, 13, pp. 318-321.

† Geol. and Nat. Hist. Survey of Canada, pt. D, Ann. Rep., 1886, pp. 29 D and $30 D$. 
"The only fossils obtained from this formation were collected by Dr G. M. Dawson at the summit of the Vermilion pass in 1884, and consist of a couple of trilobitic impressions, one of which has been identified by Prof. C. D. Walcott as Olenellus gilberti, a characteristic Lower Cambrian fossil."

My object in noticing the Bow River and Castle Mountain sections is on account of the occurrence of strata that appear to belong to the Castle Mountain group on the Continental divide at the head of Nyack creek, Montana, latitude $48^{\circ} 30^{\prime}$. These beds appear to correspond to the Cambrian and superjacent groups, as they occur in the Dearborn River section, latitude $47^{\circ} \mathbf{1 5}^{\prime}$. On the north fork of Dearborn river the Cambrian sandstone, shales, and limestones rest unconformably on the Algonkian and have a thickness of 2,205 feet. These are overlain by 1,385 feet of limestones referred to the Ordovician and Silurian and 3,255 feet of Carboniferous limestone, a total of 6,845 feet of strata, mainly calcareous, above the Algonkian. It is quite probable that it is the northward extension of the lower portion of this series, that, beneath the Carboniferous, forms the Castle Mountain group at the head of Nyack creek, and also, still farther north, in the section of $\mathrm{Mr}$ McConnell. On Nyack creek the calcareous strata are more impure and massive than on Dearborn river, 60 miles south, and they are still more so in Mr McConnell's section, 130 miles to the north.

Another feature is introduced in the Bow River series: If the specimens of Olenellus reported were from the Bow River series, then we have here the Lower Cambrian strata that are absent in the Montana sections, as there the Middle Cambrian strata rest unconformably on the Algonlsian.

Doctor Dawson has described a second or western series of "Cambrian" rocks, which he correlates with the eastern section of $\mathrm{Mr}$ McConnell.

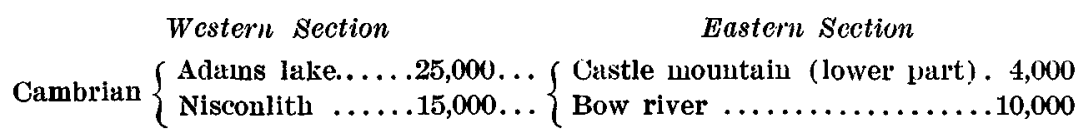

Of the eastern section he said:*

“ . . . Our typical and most carefully surveyed section is that in the Rocky mountains proper or Laramide range, on the line of the Bow River pass. This has been studied by $\mathrm{Mr}$ R. G. McConnell, and it is the only section for which some direct paleontological evidence exists. $\dagger$ The base of the Cambrian is, however, not seen in this section. In the Gold ranges, where the Cambrian is frequently found resting on the Archean, the Nisconlith, its lowest recognized

* Bull. Geol. Soc. Am., 1901, vol. 12, p. 65.

$\uparrow$ For details of the Bow River Pass section, see Annual Report Geological Survey of Canada, vol. if (N. S.), part D. 
member, varies by several thousand feet in volume, showing that the old surface was a very irregular one and had been greatly modified by denudation previous to the deposition of the Nisconlith. The same circumstance has been noticed by $\mathrm{Mr}$ McConnell in the case of the Bow River series of the Laramide range, where it is found resting on the Archean in the vicinity of the Finlay river, over 400 miles northwest of his typical section," proving this denudation interval to be a very important one, although, as already noted, there is often a parallelism in strike between the two series of rocks."

He then describes the general characteristics of the Bow River and Castle Mountain series, and then says of the Nisconlith series of the western section $: \dagger$

"Passing now to the next mountain system, to the southwest of the Laramide range and parallel with it-the Gold ranges-we find in the Selkirk mountains a great thickness of rocks that have not yet yielded any fossils, but appear to represent, more or less exactly, the Cambrian of our typical section. Resting on the Archean rocks of the Shuswap series is an estimated volume of 15,000 feet of dark gray or blackish argillite schists or phyllites, usually calcareous, and toward the base with one or more beds of nearly pure limestone and a considerable thickness of gray flaggy quartzites. To these where first defined in the vicinity of the Shuswap lakes the name Nisconlith series has been applied.t The rocks vary a good deal in different areas, and on Great Shuswap lake are often locally represented by a considerable thickness of blackish flaggy limestone. In other portions of their extent dark gray quartzites or graywackes are notably abundant. Their color is almost everywhere due to carbonaceous matter, probably often graphitic, and the abundance of carbon in them must be regarded as a somewhat notable and characteristic feature. These berls have also been recognized in the southern part of the West Kootenay district and in the western portion of the Interior plateau of British Columbia.

"The Nisconlith series is believed, from its stratigraphic position and because of its lithologic similarity, to represent in a general way the Bow River series of the adjacent and parallel Laramide range, but there is reason to think that its upper limit is somewhat below that assigned on lithological grounds to the Bow River series.

"Conformably overlying the Nisconlith in the Selkirk mountains, and blending with it at the junction to some extent, is the Selkirk series, with an estimated thickness of 25,000 feet, consisting, where not rendered micaceous by pressure, of gray and greenish gray schists and quartzites, sometimes with conglomerates and occasional intercalations of blackish argillites like those of the Nisconlith. These rocks are evidently in the main equivalent to the Castle Mountain group, representing that group as affected by the further and

* Annual Report Geological Survey of Canada, vol. vii (N. S.), p. 24 C.

† Loc. cit., pp. 66 and 67 .

† Annual Report Geological Survey of Canada, vol. iv (N. S.), p. 31 B.

Bull. Geol. Soc. Am., vol. 2, p. 170 .

Annual Report Geological Survey of Canada, vol. vii (N. S.), p. 31 B.

Shuswap map sheet, Geological Survey of Canada. 
nearly complete substitution of clastic materials for the limestones of its eastern development.

"In the vicinity of Shuswap lakes and on the western border of the Interior plateau, the beds overlying the Nisconlith and there occupying the place of the Selkirk series are found to still further change their character. These rocks have been named the Adams Lake series.* They consist chiefly of green and gray chloritic, felspathic, sericitic, and sometimes nacreous schists, greenish colors preponderating in the lower and gray in the upper parts of the section. Siliceous conglomerates are but rarely seen, and on following the series beyond the flexures of the mountain region it is found to be represented by volcanic agglomerates and ash beds, with diabases and other effusive rocks, into which the passage may be traced by easy gradations. $f$ The best sections are found where these materials have been almost completely foliated and much altered by dynamic metamorphism, but the approximate thickness of this series is again about 25,000 feet."

Of the section along the International boundary, Doctor Dawson wrote: \&

"A thickness of at least 11,000 feet of sandstones and shales of red, gray, and greenish colors, frequently alternnting and including several contemporaneous trap flows, occurs between the Continental watershed and the Flathead river. This series has not been traced into connection with the sections previously described, but it slrows some resemblance to the Selkirk and Castle Mountain groups. The occurrence of blackish calcareous argillites and sandstones at the base may indicate the presence of the Bow River series there, while a limestone at the top of the section in this part of the mountains may prove to be that of the Castle Mountain group."

Doctor Dawson considered all of the Adams Iake and Nisconlith series to be of Cambrian age. From the known presence of upward of 30,000 feet of pre-Cambrian unaltered sediments in Montana and Idaho, on the strike of the strata of the Adams Lake and Nisconlith series, it appears to be more probable that the Nisconiith and most of the Adams Lake (Selkirk) series are of pre-Cambrian age and to be correlated with the Belt terranef as developed in northwestern Montana and northern Idaho.

During the season of 1904 Dr Reginald A. Daly, of the Geological Survey of Canada, studied the section on the line of the International boundary, between the Kootenay river, at Port Hill, Idaho, and the east-

\footnotetext{
* For the Selkirk and Adams Lake serles see references above given for Nisconlith series.

$\dagger$ Annual Report Geological Survey of Canada, vol. vii (N. S.), p. 35 B.

+ Comprising greenish schists 8,100 feet, grayish schists 17,100 feet. In Bull. Geol.

Soc. Am., vol. 2, p. 168, the thickness is given in error at half the above.

$\$$ Loc. cit., p. 68 .

|| Annual Report Geological Survey of Canada, vol. I (N. S.), pp. 50 B, 51 B.

If Belt terrane is here used to include the entire series of Algonkian rocks as found in the Belt mountains and westward in Montana and Idaho.
} 
ern edge of Tobacco plains. Of this section he said in a preliminary report:*

"These sediments include an extraordinary thickness of conformable quartzite and argillites, the former dominating. The whole group has, on lithologic and stratigraphic grounds, been divided into four series. The lowest series, the Creston quartzite, is composed of 9,500 feet of wonderfully homogeneous, highly indurated, thick-platy gray sandstones. Overlying the Creston quartzite is the Kitchener quartzite, a second series of ancient, hard sandstones and interbedded argillites, carrying a high proportion of disseminated iron oxides. These rusty rocks are, relatively, thin bedded and bear very abundant sun cracks and ripple marks on horizons ranging from top to bottom of the series. The thickness of the Kitchener quartzite is about 7,400 feet. It is itself conformably overlain by at least 3,200 feet of thin bedded, red and gray argillaceous strata which, together with subordinate thin beds of light gray quartzites, make up the formation I have called the Moyie argillite. The youngest member of the four sedimentary divisions is the Yahk quartzite, composed of white to gray indurated sandstones bedded in thin to medium courses. The top of this series was not seen; the whole thickness observed is 500 feet. The total observed thickness of conformable strata is nearly twenty thousand feet. Neither the bottom of the Creston quartzite nor the top of the Yahk quartzite appearing in the sections, it is certain that this great thickness is only a minimum thickness."

"The westward extension of this sedimentary series was mapped and measured during 1903 in the boundary belt immediately west of the Kootenay at Port Hill. There the strata corresponding to the Creston quartzite are conglomerates, grits and coarse sandstones as well as fine grained sandstones, and are thus, on the whole, notably coarser than they were found to be anywhere in this season's belt. The equivalent of the Kitchener quartzite is less strongly charged with argillaceous beds than is the Kitchener quartzite east of the Kootenay. These facts point to the conclusion that the shoreline, whence the materials composing the stratified formations were derived, lay to the westward and that the open sea and deeper water lay to the eastward of the western crossing of the Kootenay river at the International boundary.

"This conclusion was strikingly confirmed on carrying the section towards Gateway. It was found that both the Creston quartzite and the Kitchener quartzite gradually became charged with interleaved beds of calcareous quartzite, calcareous argillite and siliceous limestone, betokening onen-water conditions during the formation of these sediments. In fact, the transition of the great quartzite series to certain of the more calcareous formations of the Rocky mountains has become the best working clue to the correlation of the rocks of the Purcell range with those of the Rocky Mountain front. If this conclusion be confirmed by the further eastward extension of the boundary section next year, it will mean that the Creston and Kitchener quartzites and, possibly, also the Moyie argillite and Yahk quartzites are of pre-Cambrian age. The nearest relatives of the Creston and Kitchener quartzites in the Rockies are respectively the two thick members of the Altyn limestone de-

* Summary Report Geological Survey of Canada for 1004, issued 1905, p. 96. IV-Bull. GeoL. Soc. AM., VoL. 17. 1905 
limited by Mr Balley Willis, who, in the year 1901, carried out a reconnaissance survey of the boundary belt on the Montana side.* No fossils have, as yet, been found in these old rocks of the Purcell range, but fossils of so-called Algonkian age were discovered in the Altyn limestone."

In a letter received from $\mathrm{Mr}$ Reginald $\mathrm{A}$. Daly under date of November 3 he says of the work of the season of 1905 :

"In general my section for the Livingston range is quite similar to that of Mr Willis, though I seem to have a greater thickness of the Altyn representeda thickness deduced at a point where there is no suspicion of any considerable duplication by thrusts. The same formations appear in the Galton range west of the Flathead and yet show systematic contrasts in lithologic characters when compared with the rocks of the Livingston range. These changes are at first, as one goes westward from the Great plains, quite gradual, but they quickly mount in value on the sixty-mile section across the Purcell range. In brief they seem to depend, in the large way, upon distance from the old shoreline near the crest of the southern Selkirks not far from Priest River, Idaho. The whole section made through these sediments is 150 miles long, i.e., between Priest Rtver and the Lewis thrust. The section is a cross-section, not only with reference to the present mountain axes, but also of the geosynclinal bearing the sediments. In the Selkirks at the Boundary the latter are coarse and heterogeneous; in the Purcells, medium grained and homogeneous (sandstones, now quartzites) ; in the Galton and Livingston ranges, fine grained and heterogeneous as described by $\mathrm{Mr}$ Willis. Thicknesses are very great at all the best sections. I regret to report no fossils except in the Altyn, though I have searched carefully for nearly three seasons. I am of the opinion, however, that the Siyeh limestone is to be correlated with McConnell's Castle Mountain limestone."

The Creston and Kitchener quartzites appear to belong to the lower portion of the Algonkian section, corresponding to the Prichard siliceous series of the Idaho section, or it may be that the Creston is older than the Prichard. In the diagram of sections I have made a tentative correlation on the basis that all of the Northern Idaho section of Daly is older than the Wallace and Blackfoot calcareous series.

\section{Source of Sediments}

The great development of limestone, accompanied by fine grained sandstones and shales, in the Belt mountains, the Rocky Mountain front, and westward to Idaho indicate offshore deposits. To the westward $\mathrm{Dr}$ Reginald A. Daly found the strata west of the Kootenay, corresponding to the Creston quartzite, formed of conglomerates, grits; and coarse sandstones, as well as fine grained sandstone. It is also to be noted that

\footnotetext{
* Bull. Geol. Soc. Am., vol. 13, 1902, p. 305.
} 
limestone is rarely found west of the Mission range, although the siliceous sediments are very fine, often indicating the deposition of siliceous mud rather than sands.

The great source of sediments, as suggested by Doctor Daly, must have been to the west and northwest of the Kootenay valley. A more or less shallow open sea extended eastward 300 miles or more. In the vicinity of Neihart, Montana, there is a trace of the eastern shoreline in the uplift of Archean gneiss and schist, with the basal conglomerate resting upon it. Occasional beds of conglomerate also occur in higher formations of the Algonkian 20 miles and more away from the Neihart Archean. It seems probable that the latter exposure is of an area that was soon buried by the Algonkian sediments, and that the main eastern shoreline, or land area, was still farther eastward during most of Algonkian time. From the character of the Algonkian sediments of the Little Belt mountains it also appears that the eastern land area afforded very little coarse material. It may have been low, sending only muds and solutions of lime and silica to the Algonkian sea, along with an occasional rush of sand and fine gravels.

\section{SuMMaRY}

The Algonkian rocks which form the subject of this paper represent a total thickness of $3 \%, 000$ feet and occupy an area extending from the Little Belt mountains on the southeast to the vicinity of Coour d'Alene on the west and northward into British Columbia. The Camp Creek, Mission Range section occurs near the center of this area and is taken as the type because of its great vertical extent (24,770 feet) and the fact that it is capped by Cambrian strata.

In the four sections neasured by the writer the Algonkian or Belt terrane is overlain unconformably by massive, coarse grained sandstones referred to the Middle Cambrian. The unconformity is usually indicated by great changes in the volume of the underlying strata and represents a considerable time interval. From the presence of Lower Cambrian fossils in the Bow River series of McConnell it is believed that this series was laid down during the erosion interval between the Algonkian and the Middle Cambrian in Montana.

The physical conditions under which the Belt terrane was deposited are very clearly indicated by the change in the character of sedimentation from the conglomerates, grits, and coarse sandstones on the northwest to the limestones, fine sandstones, and shales on the southeast. The land area from which these sediments were mainly derived must have 
been to the west and northwest of the Kootenay valley at Porthill, Idaho. The sediments which extend 300 miles or more to the eastward betray frequent evidences of shallow water deposition, and in the Little Belt mountains indicate that the eastern land area was of low relief and situated still farther to the east, although the presence of a limited land area is shown by the conglomerates at the base of the Algonkian section near Neihart. 
